\title{
Laredo, Texas: Gateway Community on the Texas Borderlands, Archaeological and Historical Investigations for the Laredo City Toll Plaza
}

William J. Folan

I. Waynne Cox

Anne A. Fox

Gilberto M. Hinojosa

Follow this and additional works at: https://scholarworks.sfasu.edu/ita

Part of the American Material Culture Commons, Archaeological Anthropology Commons, Environmental Studies Commons, Other American Studies Commons, Other Arts and Humanities Commons, Other History of Art, Architecture, and Archaeology Commons, and the United States History Commons

Tell us how this article helped you.

This Article is brought to you for free and open access by the Center for Regional Heritage Research at SFA ScholarWorks. It has been accepted for inclusion in Index of Texas Archaeology: Open Access Gray Literature from the Lone Star State by an authorized editor of SFA ScholarWorks. For more information, please contact cdsscholarworks@sfasu.edu. 


\section{Laredo, Texas: Gateway Community on the Texas Borderlands, Archaeological and Historical Investigations for the Laredo City Toll Plaza}

\section{Creative Commons License}

\section{(c) (1) \&}

This work is licensed under a Creative Commons Attribution-NonCommercial 4.0 International License 


\section{LAREDO, TEXAS: GATEWAY COMMUNITY \\ ON THE TEXAS BORDERLANDS,}

ARCHAEOLOGICAL AND HISTORICAL INVESTIGATIONS

FOR THE LAREDO CITY TOLL PLAZA

William J. Folan, I. Waynne Cox, Anne A. Fox, and Gilberto M. Hinojosa

Center for Archaeological Research The University of Texas at San Antonio Archaeological Survey Report, No. 116 



\section{LAREDO, TEXAS: A GATEWAY COMMUNITY \\ ON THE TEXAS BORDERLANDS, \\ ARCHAEOLOGICAL AND HISTORICAL INVESTIGATIONS \\ FOR THE LAREDO CITY TOLL PLAZA}

William J. Folan, I. Waynne Cox, Anne A. Fox, and Gilberto M. Hinojosa

Center for Archaeological Research The University of Texas at San Antonio ${ }^{\circledR}$ Archaeological Survey Report, No. 116 



\section{LAREDO, TEXAS: GATEWAY COMMUNITY}

ON THE TEXAS BORDERLANDS,

\section{ARCHAEOLOGICAL AND HISTORICAL INVESTIGATIONS}

FOR THE LAREDO CITY TOLL PLAZA

William J. Folan, I. Waynne Cox, Anne A. Fox, and Gilberto M. Hinojosa

Center for Archaeological Research The University of Texas at San Antonio Archaeological Survey Report, No. 116 

LARED0, TEXAS: A GATEWAY COMMUNITY

ON THE TEXAS BORDERLANDS,

ARCHAEOLOGICAL AND HISTORICAL INVESTIGATIONS

FOR THE LAREDO CITY TOLL PLAZA

William J. Folan, I. Waynne Cox, Anne A. Fox, and Gilberto M. Hinojosa

Center for Archaeological Research The University of Texas at San Antonio ${ }^{\circledR}$ Archaeological Survey Report, No. 116 
A 1 ist of publications offered by the Center for Archaeological Research can be obtained by sending $\$ 1.00$ to the Center for Archaeological Research, The University of Texas at San Antonio, San Antonio, Texas 78285-0658. 
In July 1980, the Center for Archaeological Research, The University of Texas at San Antonio, conducted archaeological and historical investigations at sites designated as 41 WB 36, 41 WB 37, and 41 WB 38, which are 1ocated in a residential district on the east side of the town of Laredo, Texas. These sites are represented by late historic foundations which were uncovered after a group of houses were razed to make way for a new tol 1 bridge comp 1 ex to facilitate international travel between the United States and the Republic of Mexico. A short history of Laredo and of the four house foundations excavated by the Center for Archaeological Research is presented in this report. The archaeological investigations of the structures and their associated artifacts are described and interpreted to provide a better understanding of sociocultural activities in Laredo from early historic times to the present. 
TABLE OF CONTENTS

ABSTRACT .............................

LIST OF FIGURES .................... . .

LIST OF TABLES ................... i i

ACKNOWLEDGMENTS ..................

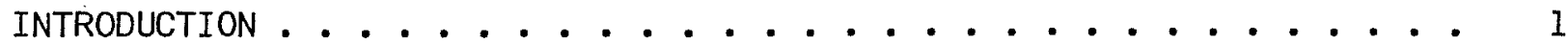

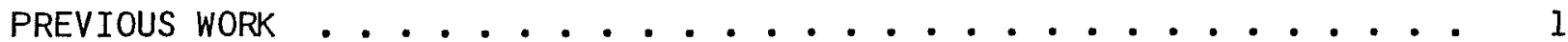

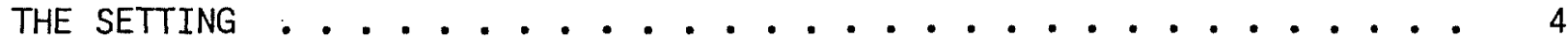

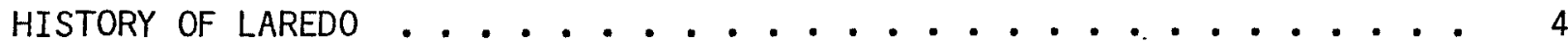

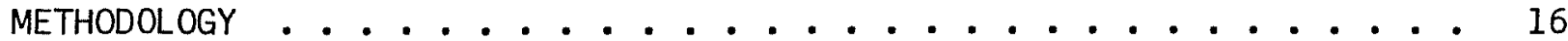

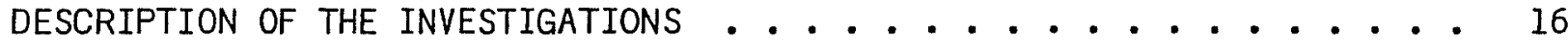

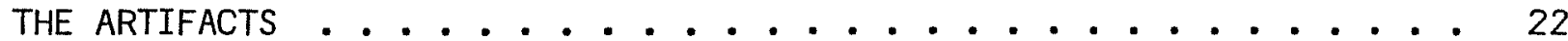

OBSERVATIONS AND COMPARISONS OF THE LAREDO ARTIFACTS . . . . . . 35

SUMMARY AND CONCLUSIONS .................. 36

RECOMMENDATIONS .................... . . . 38

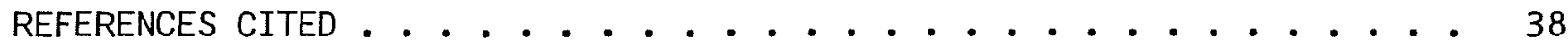

APPENDIX. NOTES ON THE FAUNAL COLLECTION FROM THE LAREDO CITY

TOLL PLAZA EXCAVATIONS (Rebekah Hajpern). . . . . . . 45

\section{LIST OF FIGURES}

1. Laredo, Texas .................... 2

2. Plan of City Block Indicating Locations and Types of Structures

During Three Periods from 1885 to $1894 \ldots . . . . . . . .10$

3. Plan of City Block 12 Indicating 19th Century and Later

Structural Foundations Uncovered on Lots 1-5 During

Project Excavations ....................... 12

4. Excavations at City Block $12 \ldots \ldots 13$

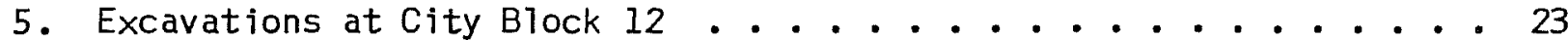

6. Artifacts from the Excavations ............. 29

\section{LIST OF TABLES}

1. Laredo Toll Plaza--Artifact Provenience . . . . . . . . . . 18

2. Suggested Artifact References . . . . . . . . . . . . . 25

3. Artifacts, Marbles ............... 32

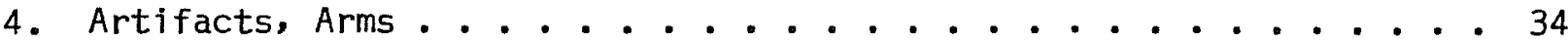




\section{ACKNOWLEDGMENTS}

We are appreciative of he1p given by Paul Garza, Jr., Dr. Leon Deking, and Ms. Ana Cruz during the field work of the Laredo Tol 1 Plaza project. Overa11 supervision for the project was provided by Thomas R. Hester, director, and $\mathrm{J}$ ack D. Eaton, associate director, of the Center for Archaeological Research. William J. Folan served as the field director. The field crew consisted of Idys Waynne Cox, Elizabeth Day, Christine DeBremaecker, Curtis Dusek, Ron Holan, Cecil Peel, and Lee Spencer. The field director would 1 ike to thank a 11 of the above people for their considerable efforts during excavation, as we11 as Anne A. Fox, Gilberto Miguel Hinojosa, and Lynda M. Florey Folan for their contributions and assistance during the 1 aboratory analysis and writeup following the excavation. 


\section{INTRODUCTION}

In July 1980, the Center for Archaeological Research (CAR), The University of Texas at San Antonio (UTSA), entered into a contract with the City of Laredo, through Paul Garza and Associates, Consulting Engineers (P. Garza, letter dated Ju1y 3, 1980), to conduct excavations at the site destined to become the Laredo City Tol1 Plaza. The investigations were done in compliance with the National Historic Preservation Act of 1966 (as amended) and its implementing regulations, 36 CFR 800, the National Environmental Policy Act of 1969, and Executive Order 11593. This complex is to be constructed at the approach to the New International Bridge spanning the Rio Grande between the United States and the Republic of Mexico. The construction area had been cleared of al1 standing architecture prior to the start of the project. Al1 that remained in the area selected for investigation were subsurface foundations of the buildings which once occupied Block 12 of the Western Division of the City of Laredo (Fig. I).

The principal objective of this project was to salvage all possible historical and archaeological information from the site prior to the construction of the Toll Plaza Building. Although sufficient time was not available before excavation to conduct archival research on the area under investigation, Idys Waynne Cox was able to gather a considerable amount of pertinent material both during and subsequent to the field work.

The areas selected for excavation had been chosen by Anne A. Fox (1980) during a June 17, 1980, visit to the site, and were subsequently confirmed as cultural resource areas by the current project. The test areas were chosen specifically because of their location adjacent to the San Agustin de Laredo Historic District. In addition, on-the-surface data indicated that the subsurface evidence of former structures was for the most part unaltered, and the areas were unhindered by piles of bulldozed building material.

In sum, the project was carried out to document the history of the area under investigation. The recording of architectural and artifactual information was done to obtain the cultural and sequential history of the buildings under investigation prior to their destruction while also determining what activities took place in this area.

\section{PREVIOUS WORK}

The 1980 project described in this report does not represent the first investigations carried out in the Laredo Toll Plaza area. The site was inspected in 1973 by personnel from the CAR-UTSA, who recommended that historical and archaeological investigations be undertaken once the associated structures had been purchased by the City of Laredo and vacated (information on file, CAR-UTSA). Additional1y, a historic study of the area was presented to the mayor of Laredo (Thompson 1974a). Following this, Bass and Hester (1975) visited the impact area to investigate the floodplain along the Rio Grande as wel1 as the area to be occupied by the Laredo International Tol 1 Bridge. They again suggested that, once a 11 structures had been acquired by the city and vacated, this locality should be checked by archaeologists and historians to make a fuller assessment of any significant cultural resources. It was 


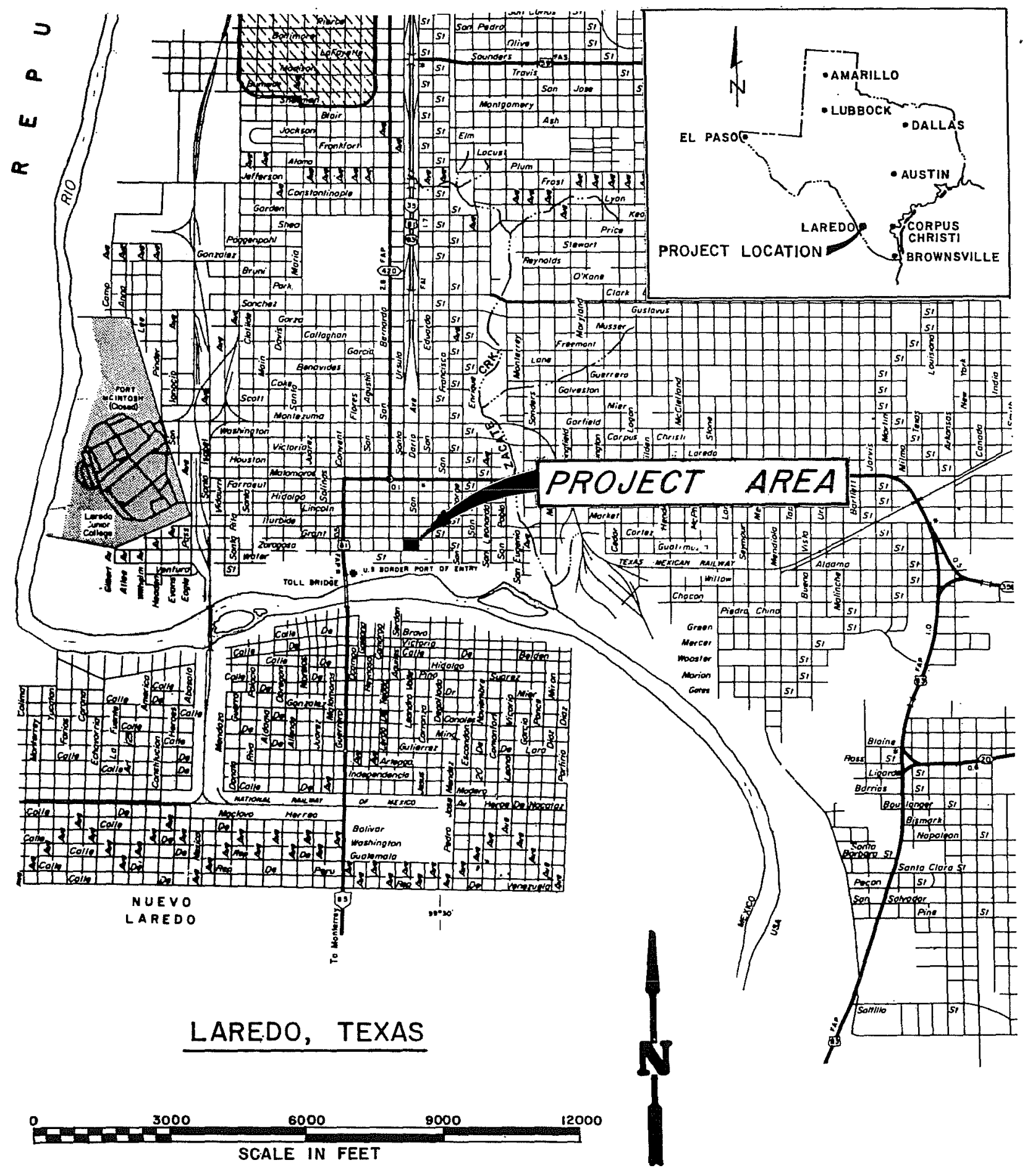

Figure 1. Laredo, Texas. The study area (City Block 12) is within the new International Toll Plaza construction zone. 
suggested by Bass and Hester (1975) that, after the clearing of the area and the demolition of the standing buildings and prior to planned construction activities involving the Tol 1 Plaza, a survey should be made of the area. They concluded that this 1 ast survey would constitute a final check for historic and possible prehistoric resources that may exist in the area. During 1980, John Clark, under contract with the Texas Highway Department, test excavated six square blocks in the right-of-way of the approach to the Tol 1 Plaza. Clark's project was situated a few blocks to the north of the CAR-UTSA project.

The CAR was not notified of the acquisition of the buildings in the study area or their vacancy, and it was not until the entire zone had been leveled that the CAR-UTSA personnel once again became involved. It was at this time, on June 17, 1980, that Anne A. Fox (1980) visited the area under investigation. As a result of her visit, it was suggested that archaeological test investigations should be carried out before the construction of the Tol $1 \mathrm{Plaza}$ to record as much surface information as possible, while also excavating to determine whether or not earlier house foundations and/or prehistoric occupations existed. It was also suggested that archival research be carried out in city and county records as well as in the Laredo Archives, and that there should be communications with local historians.

In addition to the Toll Plaza site under investigation, numerous other documented historical sites are located in the Laredo area. A series of 1 imeki1n structures to the west of town along Chacon Creek have been recorded (Peavy 1971; Hill 1971) and were visited by project personnel. Properties in the area that have been determined eligible for inclusion in the National Register are the Vizcaya de Leal House, 620 Zaragoza; the Zoila de la Garza House, 509 Iturbide Street; the Bertani House, 604 Iturbide Street; and the Leyendecker-Salinas House, 702 Iturbide Street. These are included in the San Agustín de Laredo Historic District. Other significant structures in this district are the capitol building of the Republic of the Rio Grande, the San Agustín Roman Cathol ic Church, the Cayetano de 1 a Garza home, and the Casa Vidaurri (Bass and Hester 1975).

The Center for Archaeological Research has been involved in several other projects in the Webb County area. James E. Ivey, Thomas Med $1 \mathrm{in}$, and Jack D. Eaton (1977) were responsible for initial archaeological assessment work during the spring of 1977 in areas to be modified at Fort McIntosh and Laredo Junior College. These preliminary efforts were later followed with selected testing by Thomas Medlin, Jon McClenny, and James Ivey in July 1977 (Fox 1979). They recorded subsurface structural remains in addition to many artifacts suggesting various activities covering much of the 19 th and 20 th centuries.

During October 1977, Daniel E. Fox and H. G. Uecker (1977) 1ocated three prehistoric sites during an archaeological survey of the McPherson Road extension. Fox and Uecker (ibid.) recorded dart points, bifacial tools, and secondary and tertiary chipping debris, indicating a cross section of activities associated with the production of 1 ithic tools. 
Southern Webb County has been the site of other archaeological activities. In 1969 and 1973, surveys in several areas, including a section of Zacate Creek, recorded various prehistoric sites (Shiner 1969). One site dates to the Archaic period according to Grant Hall (1973) or, perhaps, Paleo-Indian times, according to Bass and Hester (1975). In addition to the above, 63 archaeological sites had been identified in Webb County as of 1977 (Fox and Uecker 1977:3). Following this date, Thomas C. Kelly (1979) undertook survey work of the Palafox Mining area in northern Webb County. The CAR identified six prehistoric sites and several historic sites dating from the 19 th and early 20 th centuries.

A1though not located in Laredo, Texas, or the United States, the archaeologica1, ethnohistoric, and historic activities carried out by the Center for Archaeological Research in association with three Spanish missions in Guerrero, Coahuila, Mexico, should be mentioned here. These are important not only because of their proximity to Laredo but because they address both the indigenous as well as the Spanish occupation of the area from early historic times onward, including the general classes of people who occupied Laredo, both Indian and Mexican (Almaraz 1979; Campbel1 1979). A guidebook to the town of Guerrero and the missions was prepared by the CAR-UTSA as a result of these investigations (Eaton 1981). For a more generalized picture of the prehistory of the area under consideration, the reader is referred to a collection of papers edited by Jeremiah F. Epstein. Thomas R. Hester, and Carol Graves (1980).

\section{THE SETTING}

The building remains and other features investigated as part of the To11 P Taza project in Laredo are 1 ocated on the north side of B lock 12, Western Division, situated within the 1 imits of Lots 1, 2, 3, 4, and 5, mainly on and near the corner of West Grant Street and Santa Ursula Avenue. Al 1 of the structures faced West Grant Street. This area represents the first block adjacent to the San Agustin de Laredo Historic District. It is positioned on the bluff overlooking the Rio Grande within sight and sound of Laredo's sister community of Nuevo Laredo, Tamaulipas, Republic of Mexico (Fig. 1).

\section{HISTORY OF LAREDO}

In order to better understand the recent excavations in Laredo and how they fit into the general history of the city, a short history of Laredo, prepared by Gilberto Miguel Hinojosa, is presented. This is followed by a structureby-structure description of the buildings under investigation, including their occupants and alterations through time, prepared by $\mathrm{I}$. Waynne Cox.

\section{A BRIEF NARRATIVE OF LAREDO: $1755-1980$}

The size of Laredo's population, its pastoral economy, and its problems with the environment and with security resembled those of many towns in the Spanish northern provinces. Laredo's location on the Rio Grande placed it in the swirl of events which accompanied the transitions between various 
sovereignties: Spanish, Mexican, American, Confederate, and American again. The area's involvement in these transitions required Laredoans to adjust to political turnovers and dramatic population changes. The presence of European immigrant merchants in Laredo in the American period uniquely modified the relationship between Mexican-Americans and Anglo-Americans. The transitions altered the town's social structure, and contributed to divisions within the town and among various levels of government.

Established in 1755 as an outpost of Nuevo Santander, one of the 1 ast provinces settled in New Spain, Laredo weathered the ravages of a semiarid desert and of Indian raids with little assistance from the viceregal and provincial governments. When the War of Independence against Spain broke out, Laredo was spared the fighting that raged nearby, but the town suffered the effects of the war nonetheless. Laredo was soon caught in the crossfire between various belligerents who sought control of the Rio Grande area: Mexican Federalists and Centralists, Texas rebels and Mexican armies, American volunteers and Mexican resistors, Confederates and Unionists, bandits and Texas Rangers. Turmoil continued in the 1880 s when the arrival of the rail road introduced new social and political forces.

The greatest crisis was the ongoing adjustment required of Laredoans as peop le migrated in and out of the town in response to war-related events, prosperity and depression, and changing political forces. In the early days of settlement, prosperity and growth made the stationing of troops necessary. Beneficial as these forces may have been, their presence was social1y disruptive. The appointment of a captain and the assignment of troops brought into the town a large number of males who had few expectations of permanence. The wars and revolutions that $f 1$ ared around Laredo attracted and repelled immigrants thus creating a flow of people through the town which upset sex ratios, 1 aw and order, local customs, and class relationships. In 1848 a new international boundary divided Laredo, and the townspeop $7 e$ adjusted to stil1 another sovereignty and to immigrants whose culture, politics, and economic expectations were vastly different from those of Spanish-Mexican settlers. Laredo changed in size and character, retaining after 1880 on $7 y$ a faint resemblance to the villa of the Spanish period.

The problems of division and unity and of autonomy and dependence remained prominent from the early days through the American period in spite of the above. The orderly society based on family unity established by the founders was shattered very early by prosperity and growth. Later, war, depression, and the Laredoans' own divisions further divided the community. Prosperity and growth, for example, introduced conflicts over land and political power between Laredoans and successive waves of newcomers. Racial and ethnic differences, in addition to distinctions of wealth and rank, divided the community in the Spanish, Mexican, and American periods. Some conflicts were often induced by external events such as international wars, revolutions, and Indian raids, and by environmental and social factors such as drought and epidemics. Still, old settlers and new arrivals alike sought to determine their own destinies as they struggled for survival and permanence in the chaparral. 
Implementation, Growthe and Maturity: 1755-1810

E1 Seno Mexicano, arching from the Panuco River to the Nueces River and bounded by the Provinces of Nuevo León, Coahuila, and Texas, had been bypassed by settlers in the I7th century in favor of more fertile and strategic areas. But by the early 1700 s the need to formally establish a new province in the region became evident as population increased and cattle herds multiplied in the adjacent provinces. In 1746, don Jose de Escandon was selected for the mission which culminated with the founding of Laredo in 1755 by don Tomás Sanchez de 1 a Barrera y Gallardo. The city was founded on a grant on the north bank of the Rio Grande near the Paso de Jacinto, made up of 15 sitios de ganado mayor $(66,000$ acres; Wilkinson 1975:25). In 1757, when inspected by Tiendas de Cuervo, the population consisted of ". . 85 people living in 11 families" (Bolton 1902:191). By 1767 the population had increased to 200 persons 1 iving in $60 \mathrm{jaca} 1 \mathrm{es}$. It was at this time that the settlement was declared a villa or town. Each citizen received one porción, a plot 1000 varas $w i d e$ and 30,000 varas in length (approximately 10,000 acres) fronting on the river, up and downstream from the village. For his efforts in establishing the community, don Tomas Sanchez was granted two porciónes (Palacios and Ossorio 1767). At that time the town plot was officially established: ". . . the plaza marked with durable posts. The two squares fronting north and south were laid out in four lots. In the two squares facing east and west, the church was to be built fronting east, and the jail and house for the captain were to be built on the square west of the plaza" (Garcia 1970:16). The plaza was to measure 100 varas $\times 80$ varas (ca. $278 \times 222$ feet), and the town 1 ots were to be 20 varas $\times 40$ varas (ca. $56 \times$ 111 feet). The decree required that houses be constructed within two years (Palacios and Ossorio 1767).

According to the census of 1789, Laredo's population included 700 Spanish, Mulatos, and Metizos, plus 100 Carrizo Indians 1 iving within the town's jurisdiction. By that time the town consisted of a stone church and priest's house, 85 dwellings, and a barracks for the soldiers (Wilcox 1946:349). The remote village continued its slow growth but suffered heavily from Indian attacks.

\section{Larede Under Mexico: 1810-1848}

The effects on Laredo of Mexico's War of Independence against Spain were considerable. The insurgents had hoped to create a corridor across the Borderlands through which men and supplies could be sent from the United States to aid the main forces farther south. Their efforts in the Rio Grande area south and east of Laredo and in Texas created enough turmoil to disrupt the fragile stability of the town. Thus, Laredo suffered even though the residents remained uninvolved in the conflict.

The most dramatic effect of the war was the population turnover experienced by Laredo. The town's population, 1418 peop 7 e in 1819, did not increase significantly during the war and the turbulent early years of the Republic (Hinojosa 1979:135). But war-related disturbances induced large numbers of people to move in and out of Laredo, upsetting local and regional trade and patterns of household and family structures. Nevertheless, in spite of the 
many troubles bearing upon Laredo, a school was opened in the early 1820 s. Its function, however, was impaired as the region's population was pushed to and fro by forces well beyond the control of the settlers along the Rio Grande ( 1 b id.:36-43).

In the mid-1820s, Laredo enjoyed a brief period of recovery. The population size reached 2053 in 1828, but thereafter it experienced a downward turn when internal divisions threatened Mexico's integrity. After Mexico's War of Independence ended and the movement for a monarchy collapsed by the formation of the Repub 1 ic, the frontier experienced relative calm. As a result of this, Laredo's population and wealth increased. Peace and prosperity did not last very long, however. The Mexican government became distracted by problems in Texas and by the internal conflict between Liberals and Conservatives, while protection of the frontier deteriorated. The Indians then resumed raiding, and Laredo entered into a period of decline. The cattle herds decreased, the shifts in population returned, and town 1 ife was disrupted. Adding to Laredo's problems were two serious epidemics that struck the townspeop 1 e in the 1830 s. Yet Laredoans survived, and in 1835 prosperity once again seemed at least remotely possible (Hinojosa 1979:5254).

In the late 1830 s and 1840s, disruptive forces penetrated the town. Antonio Canales' Liberal revolt against the Centralist national government resulted in the sacking of Laredo. Pursuing cattle thieves, avenging Mexicans attempts to recapture Texas, volunteers, and Rangers invaded the Rio Grande area and piTlaged the town (Nance 1963:258-260, 326-327). As these disturbances drew closer and struck Laredo, shifts in population and the decrease in wealth became more dramatic than during the preceding period.

In 1846, Texas volunteers in the United States Army marched into Laredo as part of the American invasion of Mexico. Although Laredoans were shocked at first. by the occupation, the American presence was not without benefit. For once Laredoans enjoyed adequate protection, and some even profited from supplying the troops (Gulick, ed. 1927:172). Town leaders cooperated with the wartime government. Once it was evident that the conquest was permanent, however, I andowners became wary of their position and asked that Laredo remain a part of the Mexican nation. But this decision was not theirs to make; their destiny was set hundreds of miles away from the Rio Grande (Hinojosa 1979:68-70).

\section{The First American Era: $1848-1870$}

Following the troops, Americans first appeared on the border as merchants. They came with capital and with business connections. They also came as cultural and political representatives of the victor nation. The stage was set for conflict, and conflict did break out in Brownsville and in El Paso. The same conditions were not evident in Laredo, however. The American presence there was not as great, and a 11 iances between Anglo-Americans and Mexican elites softened the economic and social impact of the new post-1848 order. 
In the 1850s, the often-expressed hope that Laredo would develop into a major crossing point for trade with Mexico became a distinct possibility. The U.S. Army, stationed in newly established Fort McIntosh, provided the necessary security, and Americans and European merchants opened stores. Shortiy thereafter Mexican-Americans also became involved in merchandising. A11 groups seem to have adjusted without serious difficulty (Hinojosa 1979:85-90).

Despite the developments in merchandising, Laredo's population did not increase significantly between 1850 and 1860 . And, in fact the town experienced the same type of population turnover evident during war years. Divisions of wealth persisted, although in this first decade of American rule Mexican-American elite families shared their ruling class status with AngloAmericans and European immigrants. Among these upper class Laredoans a political and social alliance between Mexican-Americans and Europeans appears to have been formed (ibid.:103-105).

The Civil War accentuated divisions among Mexican-Americans in the Laredo area. Mexicano leadership in the town took control of the war effort and put down anti-American armed resistance in neighboring counties. Later, when Union forces threatened the town itself, Santos Benavides and his Laredo contingent resisted an attack by Mexican Unionist volunteers (Thompson 1974b:17-23). Benavides' brother, Cristobal, later owned the house on Lot 1 (41 WB 36) which was excavated by the Center for Archaeological Research.

The war also created some disorders within the town and increased the municipal debt, but it was nonetheless accompanied by a new prosperity. The cotton trade and wartime expenditures revived Laredo's economy. The new stores and the opening of several schools reflected the town's new wealth. The arrival of Reconstruction into Laredo in 1868 did not seem to change this (Hinojosa 1979:113-116).

Laredo's population rose significantly from 1306 people in 1860 to 2043 people in 1870. The changes in marital status, types of families, and occupations reflect the economic and population growth. Among MexicanAmericans the Texas-born fared somewhat better than the recently arrived Mexican-born. But, as a whole, Mexican-Americans retained and increased their wealth and status in the town during the decade (ibid.:128-132).

Larede After the Railroad: 1870-1886

Indian raids and banditry threatened the established order along the border in the 1870s, but Laredo survived this, and population and wealth increased throughout the decade. Laredo's importance as a border crossing also grew, culminating with the construction of the railroad connecting the Gulf coast and the markets of central Mexico. In politics, Mexican-Americans, under the Benavides leadership, recovered in the 1870 s after the mild setback suffered during Reconstruction. With the arrival of the railroad in the early $1880 \mathrm{~s}$, Laredo's population soared from 3521 citizens in 1880 to 11,319 citizens in 1890. The new immigrants from the United States with capital and business connections upset the local structure, a situation which gave rise to new conflicts, resulting in a riot in 1886 (Wi cox 1941:1-5). Thereafter Mexicanos lost control as Laredo passed into a new American era. The town's 
population continued to increase, reaching close to 15,000 peop 1 e by 1910 (Texas Almanac 1950).

Laredo After the Mexican Revolution: 1886 to Present

The Mexican Revolution initiated an unprecedented exodus from Mexico. Disrupted by political and economic turmoil, some rich and educated Mexicans, and many more poor and 1 andless peasants, followed the al ready established migratory patterns north across the border. Technological developments in the Southwest, new well drilling methods, more efficient farming, and better transportation opened vast regions where farm workers from Mexico 1 abored. Many immigrants to the Southwest crossed through Laredo. Of these, some stayed as increased connections between Mexico and the United States encouraged further development of the town. By 1930, after two decades of immigrations, Laredo's population had grown to 32,618 (Texas A1manac 1950).

The establishment of an air base within the city 1 imits as wel 1 as energyrelated discoveries in south Texas after World War II gave rise to service industries in Laredo. This, together with the ever rising demand for American goods, drew more immigrants to the city. The 1 arge number of newcomers-both poor Mexicans and Mexican-Americans, and middle class Mexican-Americans and Anglo-Americans in professional and managerial occupations--have challenged the power of the first settlers and the merchants (European and Anglo-American) from the early railroad years. The increase of a permanent population has created a new sense of identity among Laredoans reminiscent of that of the first wave of pobladores who staked their lives and future in this chaparral region.

\section{ARCHITECTURAL HISTORY OF THE AREA INVESTIGATED (see Fig. 2)}

A considerable amount of information was gathered about the structures under investigation. In addition to archival research, individuals familiar with the neighborhood in which the crew was working were sought out and questioned. Some local people stopping to watch the excavations were also asked about the structures under investigation. Unfortunately, however, most of these people found it difficult to orient themselves in the area because virtually all 1 andmarks familiar to them had been demolished. An active but unsuccessful effort was made to acquire from $10 \mathrm{cal}$ residents photographs of the area where the crew was working. However, none were forthcoming.

A detailed record of the persons who resided on the south side of West Grant Street and of their lots and architectural possessions follows. Although the record dates on $1 y$ to the mid-19th century, this information is useful to understand the excavated remains.

\section{Lot 1}

The earliest structure excavated on the northwest corner of Lot 1 (designated as 41 WB 36), B 1 ock 12, Western Division, is now represented only by the remains of a 20- $\times 30$-foot wall foundation built of sandstone and sandy 1 ime 
$J U L Y 1885$

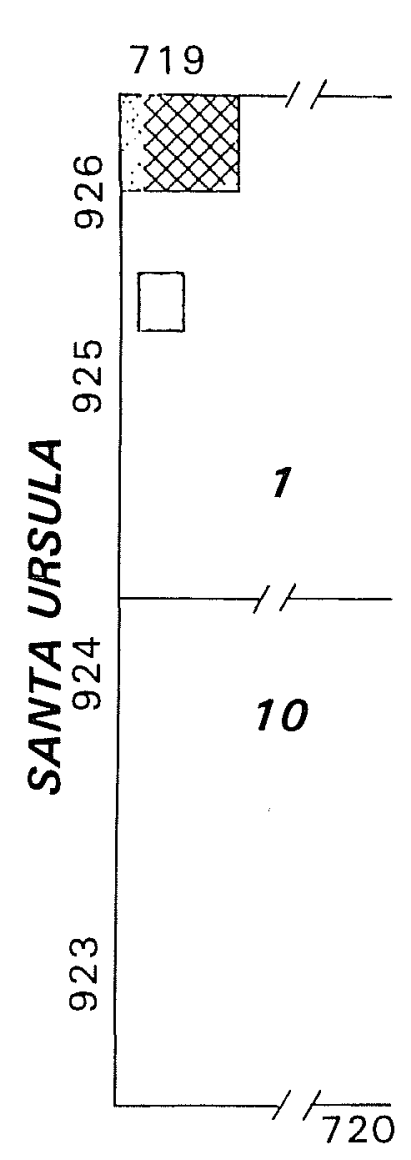

$a$
JULY 1889

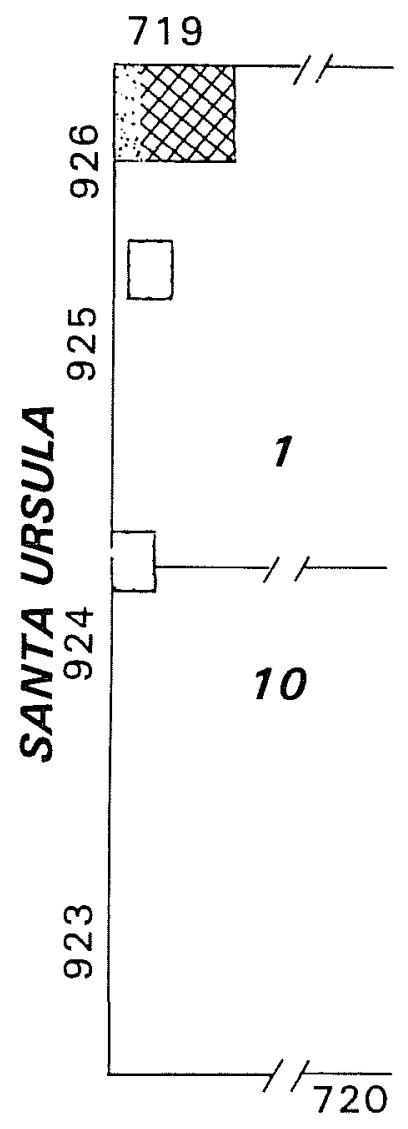

b

\section{FEBRUARY 1894}

W. GRANT

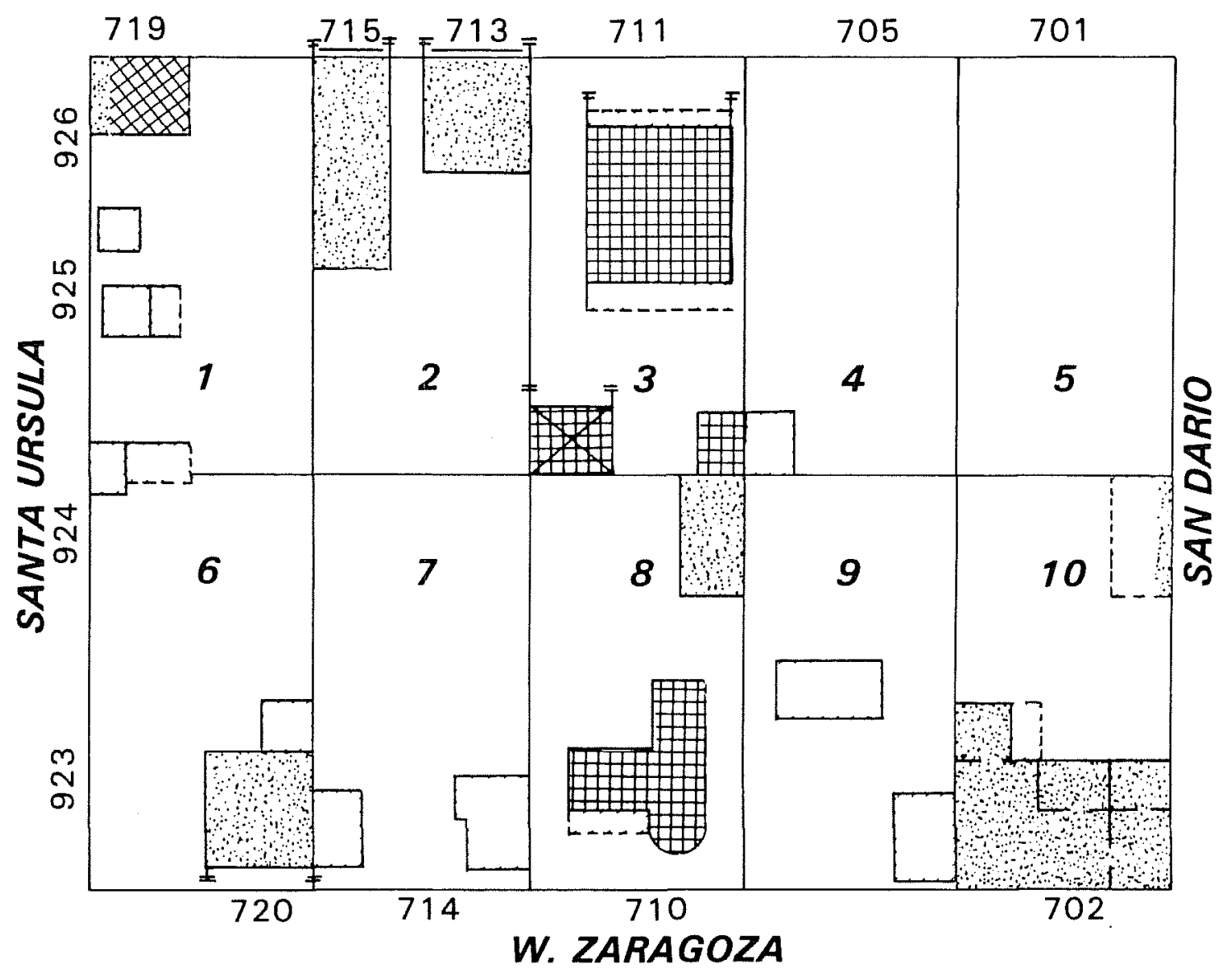

STRUCTURAL LEGEND
$\begin{aligned} & \text { Stone } \\ & \text { Adobe }\end{aligned}$

C

Figure 2. P1an of City Block 12 Indicating Locations and Types of Structures During Three Periods from 1885 to 1894. Based on Sanborn insurance maps for the periods. a, two structures on Lot 1 in 1885; b, three structures on Lot 1 in 1889. The insurance maps do not indicate occupation of the other lots on the block during these periods; c, structures are indicated on a11 lots except Lots 4 and 5 in 1894. 
mortar and associated artifacts (Fig. 3). Exactly when this house was constructed and of what its original superstructure was built cannot be determined at this time. However, it was standing prior to 1868 and was probably built of adobe, or stone, or both.

The first owner of Lot 1 appears in the 1855-1868 11isting of Laredo property owners under the name of A. Mareno (Laredo City Directory 1855-1868). In 1879. Mario Antonio Ruis de Mareno sold the property to a Mr. Ramon (WCDR Vo1. 8:274). On February 8 of the following year, Mr. Ramon transferred the tit 1e to Christoba 1 Benavides for $\$ 300$ (WCDR Vo1.9:159). By 1885, a house described as being of stone and adobe is shown on this 1 ot according to the first Sanborn insurance map of Laredo (Sanborn Map and Publishing Company, Ltd. 1885; Fig. 4,a). This may be the same house included in a "Perspective Map of the City of Laredo, Texas" (Reps 1973:641), drawn sometime around 1890.

From the above it may be inferred that the first house recorded in Lot 1 was constructed on a sandstone foundation sometime between approximate1 y 1828 when Laredo streets were 1 aid and 1885 when it appears on the Sanborn map. In 1889, the Sanborn map (Sanborn Map and Publishing Company, Ltd. 1889) shows the house still standing and unaltered (Fig. 2,b) as does the 1894 map (Sanborn Map and Publishing Company. Ltd. 1894; see Fig. 2,c). Sometime after this date, the house was razed to make way for the construction of a brick home. It is around this time that Laredo is described as being the source of the best and the cheapest brick in Texas, according to the propaganda-oriented "Perspective Map of the City of Laredo, Texas" (Reps 1973:641). Records show that Christobal Benavides died in 1904, and his widow subsequently sold the property to their son, Santos, for $\$ 1.00$ "out of Tove and affection" (WCDR Vo1. 43:174). Santos, who probably built the brick home, retained the property until April 1913, when he sold it to Alfredo $A$. Garcia and his wife, Teresa, for $\$ 12,000$ (WCDR Vo1.60:382). The fol 1 owing year the property was sold to Santos' son, Servando Benavides, a prominent rancher of the area (WCDR Vol. 61:237). At that time the house was occupied by Cesare Gomez (Payne 1913), suggesting that Servando did not 1 ive there but retained his residence on Lincoln Street. Upon the death of Servando Benavides in 1941, the house, by then described as an "old brick house," was transferred to his married daughter, Angel ina Benavides de Longoria (WCDR Vo1. 212:164-165; Probate Records, File 2628). Angelina, in turn, willed the property to her unmarried daughter, Maria Angel ina Longoria, who assumed ownership upon her mother's death in 1960. Maria, 1ater married to Fernando Garcia Moreno, transferred the property to her son, Fernando Carlos Marcglo [sic] Garcia Moreno Benavides in 1970 (WCDR Vo1. 429:437-443). Fernando, in turn, willed the property to his married daughter, Maria Elena Garcia Moreno Benavides de Ayala, upon his death in 1972 (Probate Records, File 190016).

In addition, located behind the adobe and stone main structure was a single, sma 11 wooden structure facing Santa Ursula Avenue (Sanborn Map and Publishing Company, Ltd. 1885). By 1889, another similar structure was shown to the south of the first wooden structure. By 1894, the first wooden structure remained the same, but the second building had been enlarged with an addition to the rear and another two-room wooden structure had been added to the 


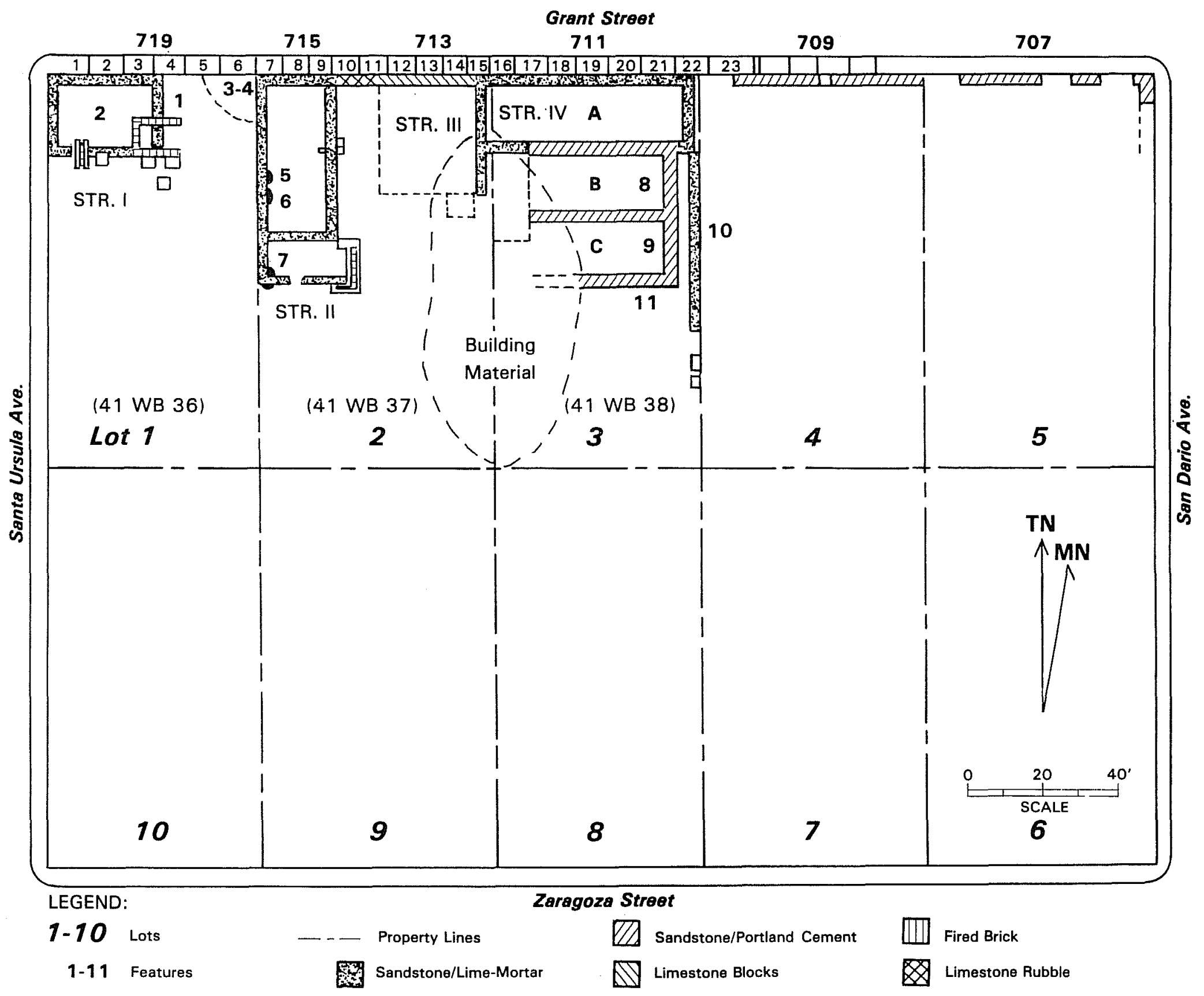

Figure 3. Plan of City Block 12 Indicating 19th Century and Later Structural Foundations Uncovered on Lots 1-5 During Project Excavations. 


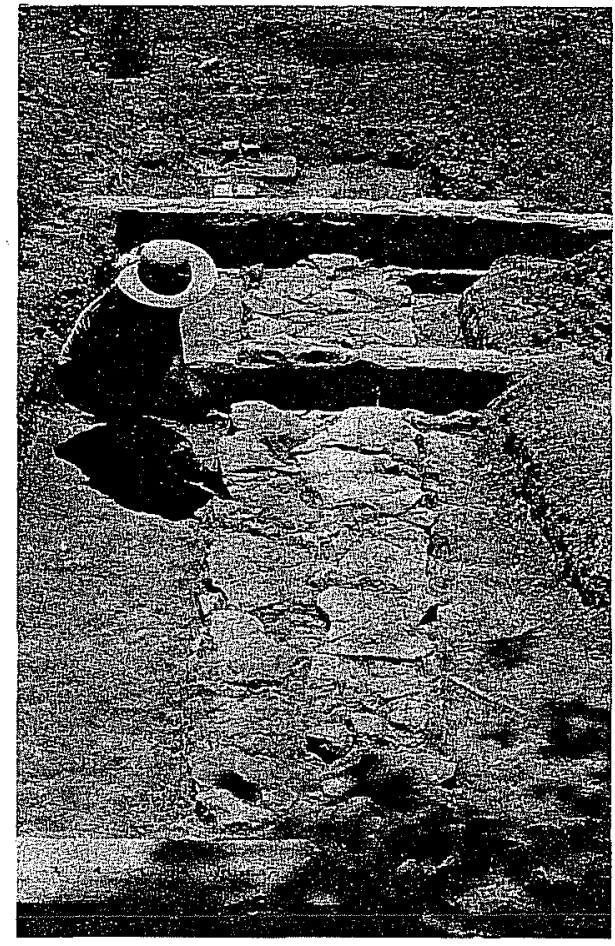

a

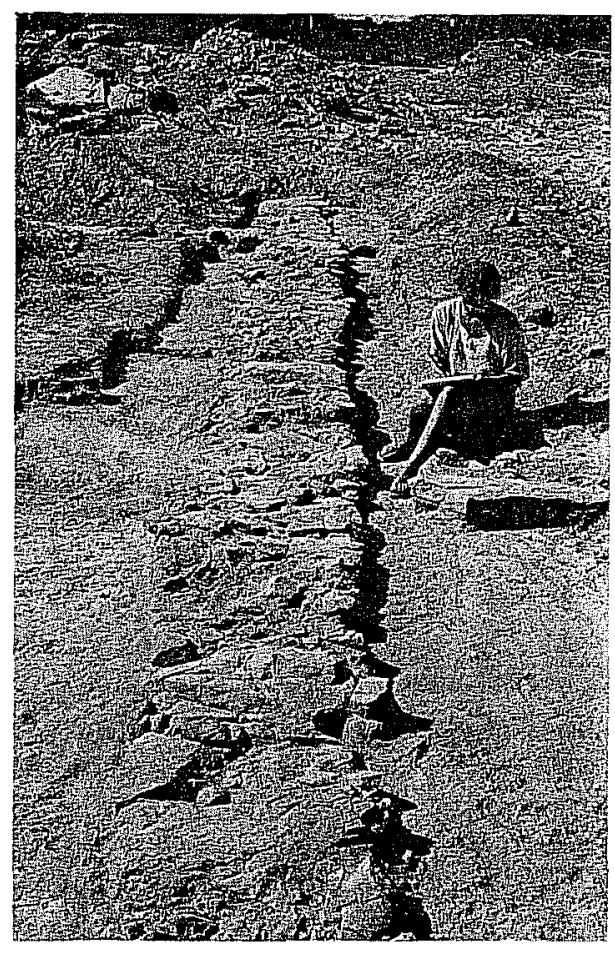

c

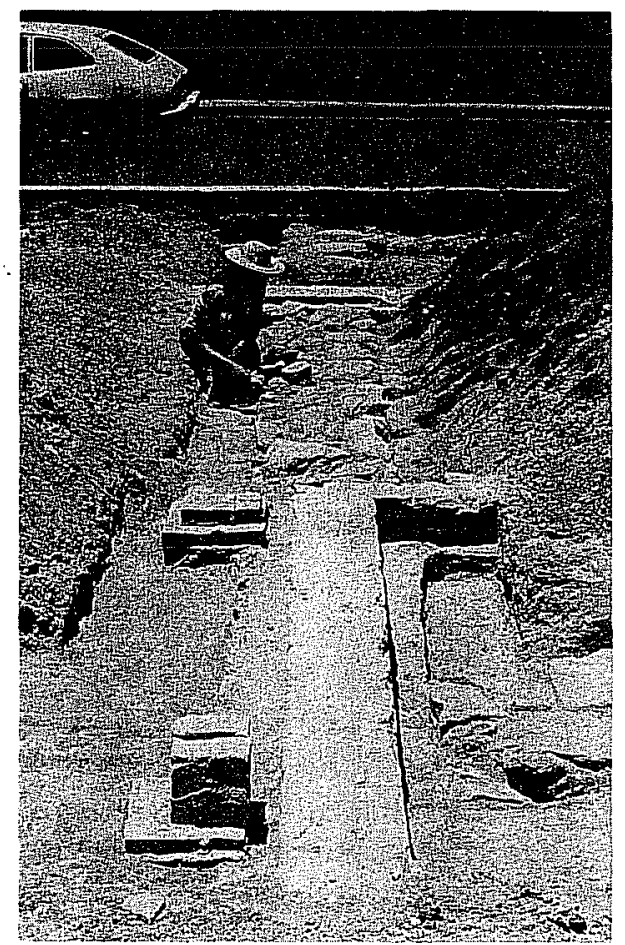

b

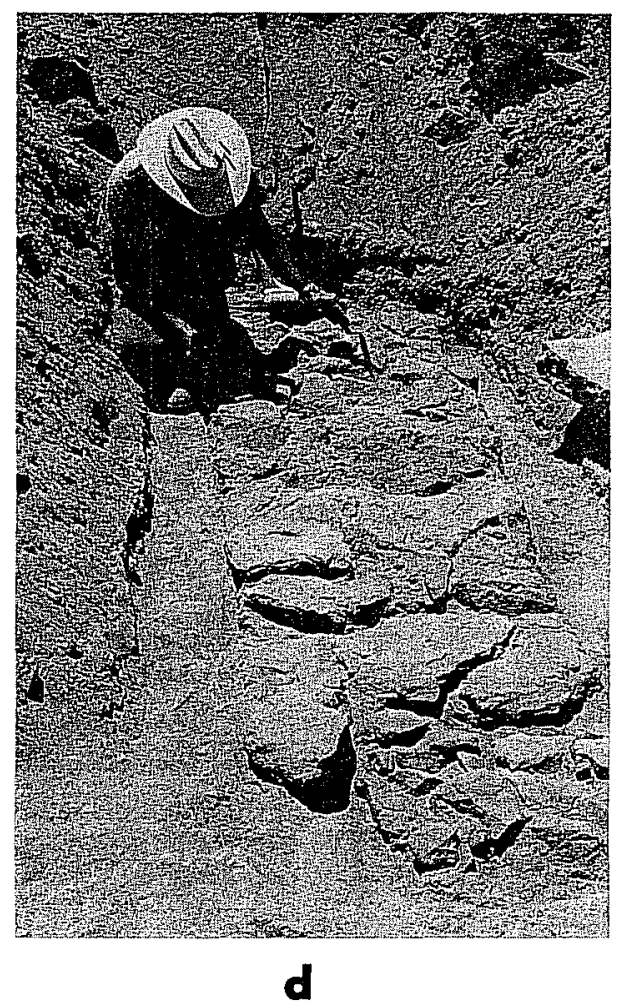

Figure 4. Excavations at City Block 12. Shown are views of 19th-century house foundations. a, Structure I, looking south. Shown is a west trending sandstone foundation crossed by a later brick foundation; b, Structure I, looking south. Shown are porch piers at rear of building; c, Structure II, west foundation; d, Structure III, east foundation. 
south. AT1 of these buildings were described as "Mex. Shanties" (Sanborn Map and Publishing Company, Ltd. 1885, 1889, 1894; see Fig. 4,a-c).

In 1975, a map of B 1 ock 12 by Paul Garza, Jr., provides a plan view of the house inherited by Fernando's daughter. It is described as a brick house built on a concrete slab. There is a front porch forming the northeastern half of its facade that is 1 inked to the sidewalk fronting the house by a concrete walkway. Instead of the temporary buildings described above, the 1975 plan of Lot 1 includes the floor plan of a fairly large L-shaped garage located in the southeastern corner of the lot, facing and 1 inked with Santa Ursula Avenue by what seems to be a concrete driveway with a divided center.

Lot 2

Two structures divided by a 1 ane were constructed on Lot 2 (designated as 41 WB 37) without the apparent addition of auxiliary structures until very recent times. The building to the west is now represented on 1 y by a $20-x$ 54-foot sandstone and sandy 7 ime mortar foundation. The building to the east facing West Grant Street, in contrast to the one to the west, was supplied with a 27-foot 1 imestone foundation joined by sandy 1 ime mortar. The remainder of the foundations associated with this building were, however, built of sandstone joined by 1 ime mortar (Fig. 3 ).

Lot 2 is recorded in the Laredo property 1 isting of 1855-1868 as belonging to Cecil io Vil1 areal (Laredo City Directory 1855-1868). In 1871, Vi 11 area 1 entered into an agreement with Jesusa Flores, the owner of neighboring Lot 3 , to jointly share a stone wal1 erected on the dividing line separating their two properties (WCDR V01. 10:502-504). This would seem to suggest that the sandstone foundation house located on the western section of Lot 2, at 715 West Grant Street, had al ready been constructed when the 1 imestone-fronted house was under construction. In 1894, both buildings appear for the first time on the Sanborn map (Sanborn Map and Publishing Company, Ltd. 1894) as two stone buildings separated by a 1ane. Sometime after 1894, the two buildings seem to have been joined to form a single structure, as the city directories after 1900 no longer 1 ist the 1 imestone-fronted residence at 713 Grant Street.

In 1900, the house at 715 West Grant Street was rented by $\mathrm{C} 1$ arence and Hiram E. Hasting, who would appear to be among the first Anglos to move into this area (Arguindegui and McDone 11 1900). In December 1901, Marcedonia, the widow of Villareal, sold the property to Apolonio Botel 10 (WCDR Vol. 4:374). Apolonio, in turn, passed the property to his heir, Nicolasa G. Botel 1o. She apparently passed it to Delia Botel10, who resided there until the City of Laredo acquired the property. In 1975, this structure is recorded and described as a single structure, stucco house on a concrete slab built flush with the sidewa7k, as were so many early homes in Laredo. In addition to the main building a small rectangular-shaped structure is situated in the southwestern corner of the lot (Garza 1975). 
Lot 3

The principal structure built on Lot 3 now consists on 1 y of a foundation built of sandstone and set with sandy 1 ime mortar, measuring $57 \times 20$ feet. A sandstone and cement mortar foundation addition, measuring $29 \times 31$ feet, was built to the rear of the earliest foundation at a later date (Garza 1975).

Dubigen Molina is 7 isted as the owner of the property according to the 18551868 Laredo City Directory. By 1871, however, it had been acquired by Jesusa Flores. It was at this time that the first sandstone foundation structure was built according to the nature of the agreement mentioned above between Flores and his neighbor Cecilio Villareal to share a common wall (WCDR Vol. 10:503-504). In 1886, the property was sold to satisfy back taxes. It was purchased by Honor Lagarde, who 1 ater became tax coll lector for the City of Laredo (WCDR Vol. 14:335). By 1895, the first structure recorded on this 1ot had been razed and replaced by a brick building probably constructed by Lagarde (Sanborn Map and Publ ishing Company, Ltd. 1894). In that Lagarde's actual residence was located in the next block, this would suggest that he either constructed the home for the future use of his children or for investment purposes. Meanwhile, Santos Benavides resided there in 1900, apparently renting the residence from Lagarde (Arguindegui and McDonel 1 1900). In 1902, Honor's widow, Maria E. M. de Lagarde, sold the property to M. S. and H. Sanchez (WCDR Vo1. 27:437). In 1911, Herminia Sanchez, a minor child, apparently orphaned, sold the property to Inocente Farias (WCDR Vol. 59:539). In 1935, Alfredo Pellegrin, a shoe salesman, 1 ived in the residence (Jackson 1935). The property was sold in 1941 to Elana, Sofia, and Juana Zuazua. In 1957, the property was acquired by a relative, Luisa Zuazua Kirkpatrick (WCDR Vol. 169:266-267; V01. 255:106-107). In 1972, Luisa transferred the property to the Missionary Society of the 0blate Fathers of Texas (WCDR Vol. 439:123-124). They maintained ownership until the property was acquired by the City of Laredo to make way for the construction of the Toll Plaza. At that time the structure was described as a brick house with a front porch and yard 1 inked to the sidewalk by a cement walkway. A rear porch is also shown, as is a brick patio to the rear of the building which is associated with a rectangular storage room situated in the center rear section of the 1 ot. What appear to be minor patios are located to the east and west of the brick patio. Another minor patio is shown located to the northwest side of the main structure (Garza 1975).

\section{Lots 4 and 5}

According to the Sanborn insurance map of 1894 (Sanborn Map and Publishing Company, Ltd. 1894), no architectural features, except for a very sma 11 building, are shown as associated with Lots 4 and 5 . Not even a sidewalk is shown fronting West Grant Street (Garza 1975; Fig. 2,c.). 


\section{METHODOLOGY}

Before beginning the excavations, it was decided to concentrate investigative activities on visible building traces. This decision was based on the insecurity associated with the existence and condition of subsurface features due to the demolition and subsequent leveling of a 11 architecture in the genera 1 area with the use of heavy earth-moving machinery. A simple, direct approach was devised to excavate the greater part of the major architectural features still intact within Lots 1,2 , and 3 of $B$ lock 12 , and to record al1 associated artifacts, enabling the excavators to determine their chronological placement. The project was also interested in learning about the various activities carried out within and around the site 1 imits. With these thoughts in mind, a series of sequentially numbered control units was delineated, using the sidewalk expansion cracks along the West Grant Street sidewalk and extending from the west toward the east. Similar-sized control units were sequentially lettered on the sidewalk on Santa Ursula Avenue from north to south. This grid recording technique was used because it was thought that heavy pedestrian traffic in the area would probably disturb a staked grid system. As the major subsurface elements of the investigated structures were discovered, al1 associated masonry was followed to expose the complete plan of the foundations wherever possible. Excavations of the foundations were photographed and mapped before deeper excavations were made along selected sections of each foundation wall down to the base. This was done to provide a more complete picture of the foundation wal1 $1 \mathrm{~s}^{\prime}$ composition and limits while also enabling the generation of cross section drawings of each of these masonry features.

During excavations, most of the material excavated from structures and features was screened through 1/4-inch hardware cloth. Al1 artifacts collected during excavation or collected from the screen were placed in bags previously marked to indicate their provenience. These artifacts were 1 ater cleaned, 1abeled, catalogued, identified, and analyzed in the CAR 1 aboratory at The University of Texas at San Antonio. Al1 artifacts are curated at the CAR-UTSA.

\section{DESCRIPTION OF THE INVESTIGATIONS}

Before excavation began, al1 grass and weeds were removed from the study area, including from the cracks in the sidewalk and street bordering the area. By doing this, upper sections of the remaining subsurface masonry became visible, as well as certain features associated with the sidewalk and street. Once this considerable task had been accomplished, the area was swept with stable brooms to reveal and clarify additional architectural and other features before beginning excavations. Standard procedures were used, employing the use of shovels, trowels, brushes, and screens. 
Lot 1 (41 WB 36)

Structure I

The first structure revealed by the excavations was a modest building, probably of stone and adobe, situated on the northwest corner of Lot 1 at what was 719 West Grant Street. The remains of this building are now represented by a 20- $\times 30-$ foot sandstone foundation 1 aid with sandy 1 ime mortar (Fig. 4,a). After this building was razed, a 1 ater brick structure with a porch protruding from its southeastern rear corner was built on a yel low brick foundation set with Portland cement. The brick foundation was built in the same area as the earlier building and enclosed approximately two-thirds of it (Fig. 4,b). The bricks are best described as low-fired and are imprinted with the designation "Mexico." Piers formed of the same type of yellow brick served to support the porch situated to the eastern rear section of this building. At a later date, a chain-link fence was erected to enclose the front yard of the later period house. Both the steel posts from which the fence was hung and the fence itsel $f$ were encased in concrete at their lower edge. This fence was divided near the center of the structure by the concrete walk linking the house to the sidewalk.

In addition to the building remains, four cultural features (Features 1-4) were recorded on Lot 1 . These features were characterized by charcoal deposits or other stained areas associated mostly with historical household or construction materials. Included were such items as ceramics of various types and miscellaneous glass and metal fragments. General kitchen refuse, such as fragments of animal bone, was also recorded.

Feature 1 was an activity area located along the eastern face of the east foundation of Structure I. Feature 2 was marked by a reddish colored soil within the confines of the original sandstone foundation. Both of these features were associated with fragments of ceramics, glass, meta 1 , bone, she11, and other artifacts (Fig. 3; Table 1).

Features 3 and 4 were the most prominent components associated with Lot 1 . Together these two features form a single charcoal stained area, perhaps used as a hearth, located to the east of the earliest foundation wall of Structure I. These features predated and had been intruded upon by the formation of the west foundation wall of Structure II on Lot 2. Features 3 and 4 contained a wide variety of artifacts, including ceramics and glass (Fig. 3; Tab 1e 1).

Lot 2 (4I WB 37)

Structure II

Litt 1 e is known about the earliest architecture associated with Lot 2, as nothing appears on the Sanborn maps of Laredo unti1 1894 (Sanborn Map and Pub 1 ishing Company, Ltd. 1894; Fig. 2,c). Original1y, this 1 ot was thought to be associated with only a single structure situated on its western 1 imits. However, subsequent examination of the Sanborn maps indicated that two structures rather than a single structure are represented (Figs. $2, c ; 3$ ). 


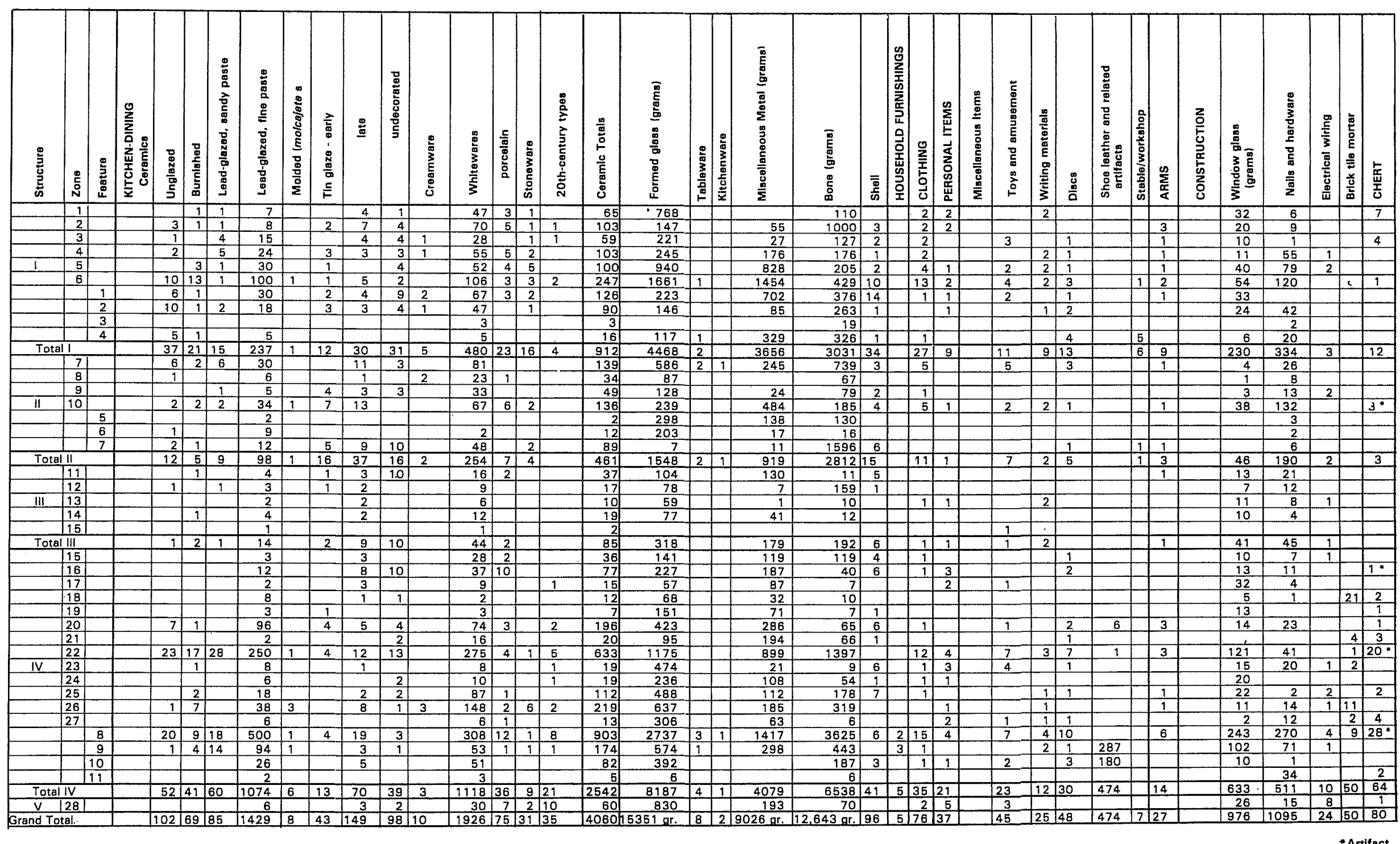


The first, designated here as Structure II, was 10 cated at 715 West Grant Street. It was a stone building in 1894, now represented only by a rectangular foundation built of sandstone set with sandy 1 ime mortar (Fig. $4, \mathrm{C}$ ). The foundation measures approximately 55 feet north-south by 22 feet east-west. Following the construction of the original building, a modern style bathroom with plumbing was appended to the rear of Structure II sometime during the 1920 s.

Three cultural features (Features 5-7) were found associated with Structure II. Feature 5 consisted of a posthole associated with a smal1 trash pit containing mainly fragments of glass, metal, and bone. This feature was recorded in 1 ine with the foundation west wal1. Feature 6 was also represented by a posthole characterized mainly by fragments of formed $\mathrm{g} 1$ ass (Fig. 3; Table 1).

Feature 7 was more clearly defined than the others and contained a great many more artifacts. According to field notes, this feature represents a historic, multilayered trash pit underlying and therefore predating the southwest corner of the sandstone foundation of Structure II. The overal1 dimensions of the feature are 10 inches in diameter and 24 inches deep. In addition to a British style gunflint, the trash pit contained large quantities of bone fragments mixed with ceramic sherds, glass, shel1s, and other objects (Fig. 3; Table 1).

A smal1 trash deposit was also identified in the approximate center of the east foundation wal1 of Structure II. It appears to have been a drainage pipe and contained a bottle and other objects (Fig. 3; Table 1).

\section{Structure III}

Structure III, once a stone structure 1 ocated at 713 West Grant Street, is now represented by the remains of a 30- $\times 22-$ foot foundation mostly covered by a large pile of bulldozed building material (Fig. 3). This foundation is built of rubble 1 imestone set with sandy 1 ime mortar along its northern 1 imits, and slab sandstone for the foundation walls to the east, south, and west (Fig. 3).

Little is actually known about the building that once stood here other than the construction and $\mathrm{p} 1$ an of its original foundation and the addition of a smal1 brick room to the southeastern corner of the rear wal1. As suggested by Paul Garza's (1975) map of Block 12, Structure II may have been joined with Structure III to form a single unit.

Because most of the building foundation of Structure II was covered by a 1 arge pile of building material refuse, 1 ittle additional excavation was carried out other than that essential to define principal remaining architectural components. No other significant cultural features were noted. 
Lot $3(41 W B$ 38)

\section{Structure IV}

Little is known about the building or buildings which stood on Lot 3 prior to 1894, when a structure first appears on Sanborn's map of Laredo (Sanborn Map and Publishing Company, Ltd. 1894; Fig. 2,c). The earliest building was a rather smal1 structure now represented on 1 y by a sandstone and sand- 1 ime mortar foundation measuring $20 \times 55$ feet and fronting West Grant Street (Fig. 3). The front foundation wall is pierced by eight $4 \times 6$-inch postholes filled with fragments of wooden posts that evidently served as door jambs and as support to the roof of the original building.

Following the construction and occupation of the earliest building, it was eventualiy razed at an unknown time, a two or more room yel low brick addition was built to the south of the original building on a sandstone and Port 1 and cement foundation ( $\mathrm{Fig} .3$ ). What appears to be an interior, rectangu 1 arshaped division oriented north to south is visible along the western interior of the brick foundation. Further investigation of this feature was impaired by the pile of building debris mentioned above. According to Garza's 1975 plan, however, the area seems to represent a small patio.

A foundation built of rubble sandstone set in sandy 1 ime mortar was discovered to the east and south of the earliest foundation, which is built of the same material. The wall may have served as a property divider between Lots 3 and 4 at the time that the earliest structure was built. What may represent the sil1 of a doorway joining the two lots was recorded in the northern portion. The doorway probably opened into Lot 4 (Fig. 3 ).

The brick building seems to have been the one recorded on Sanborn's 1894 map of Laredo (Sanborn Map and Publishing Company, Ltd. 1894) as a fairly 1 arge brick structure on Lot 3 , with a wooden porch adjoining both the front and the rear of the building (Fig. 2). By this time, the earliest structure discovered by the project crew had been razed, and the space former $7 y$ occupied by it had been converted into a front yard, as was noted for Structure I on Lot 1.

A though the crew was not aware of their existence during the investigations in Laredo, it seems worthwhile to note that two additional brick buildings are recorded on Sanborn's 1894 map of Laredo (ibid.). Both were situated at the rear of the 1ot. The one built at the southwest corner was a fairly 1 arge structure. It may have been used as a coachhouse in 1894 and perhaps as a garage 1 ater. There appears to be a 1 ane to the west of Structure IV. The other building was situated at the southeast corner of the 1ot. It is smaller and joins a similar wooden building on the southwest corner of Lot 4 (Fig. $2, \mathrm{C})$.

Several other cultural features (Features 8-11) involving specific activity areas were recorded in association with Structure IV. Feature 8 is represented by trash discarded in the area of Room $B$, and included 1 arge amounts of $\mathrm{gl}$ ass and bone. Feature 9 consists of al1 cultural material collected from Room $C$ of the same building. This collection was smaller than that recorded in Room B. Feature 10 consists of the artifact collection made 
along the property wa 11 between Lot 3 and Lot 4. This feature col 1ection had a smaller variety of ceramic wares than that found at Features 8 and 9. Perhaps this was due to its location outside of the building. Feature 11 represents the area where artifacts were collected outside of Room C. Once again the relatively $10 \mathrm{w}$ quantity and variety of artifacts collected is probably due to the location outside the building.

\section{Lots 4 and 5}

A1though originally no archaeological investigation of these lots was planned, an effort was made to at least provide as complete a record as possible of the northern perimeter of Block 12, Western Division, formed by West Grant Street (Fig. 3). The on 1 y architectural feature excavated and recorded was a sandstone and cement foundation that once supported a property wa 11 running parallel to the sidewalk fronting West Grant Street (Fig. 3 ). This wall turned a corner and continued south along the sidewalk fronting San Dario Avenue.

The sandstone and cement foundation was interrupted once in the center of Lot 4, perhaps indicating the existence of an entryway, and three times by modern driveways leading into Lot 5. The 1 atter features would seem to support the possible existence of an automobile repair garage on this lot before it was purchased by the City of Laredo. However, nothing of this nature is indicated in Garza's 1975 plan of this lot.

The on $1 y$ architecture shown for these 1 ots on Sanborn's 1894 map of Laredo (Sanborn Map and Publishing Company, Ltd. 1894; Fig. 2,c) is the sma11 wooden structure at the southwest corner of Lot 4 al ready mentioned in association with a similar structure on Lot 3.

It might be suggested that Lots 4 and 5 were the property of the family that once owned the Shiner residence situated on Lot 6 to the south of Lot 5 . It may also have been used by them at one time as an orchard or for some other activity not requiring 1 arge structures, a possibility reflected by the 1890 "Perspective Map of the City of Laredo, Texas" (Reps 1973:641) which depicts this 1 ot as uninhabited.

The Shiner residence was built in 1855. Prior to destruction, it bore a historical marker because the house was representative of a particular architectural style that at one time had been deemed worthy of preservation (Bass and Hester 1975).

\section{Sidewalks}

Effort was made during the field work to record modern features associated with the sidewaik fronting Lots 1-5 on West Grant Street. The sidewaik, 1aid after the erection of the earliest buildings fronting the street, was associated with expansion seams, curbs, driveways, water and gas service features, parking meters, lamp posts, and utility poles (Fig. 3). 
A series of sidewalks, especially those fronting 719, 717, 711, and 702 West Zaragoza Street, was also investigated. In preparation to record these areas, they were first weeded and then selectively excavated with pick, shovel, and trowel before being swept with stable brooms to make visible the materials of which they were formed and the patterns selected by their developers. The project crew was informed by an elderly passerby that both the materials and patterns of the sidewalks varied from place to place because the owner of each house fronting the street was individually responsible for supplying the materials, design, and laying of the sidewalk fronting his home. For example, some sections of sidewalk on the south side of West Zaragoza Street were of brick 1 aid in a herringbone pattern (Fig. 5,a), while another was laid in a linear pattern perpendicular to the curb (Fig. 5,b). The sidewalk fronting the Shiner house at 702 West Zaragoza Street was composed of tiles decorated with swirl designs (Fig. 5,C). Other sidewalks were of irregular slabs of flagstone carefully set to form a smooth, continuous surface ( $F$ ig. 5,d). A 11 sidewalk sections were serviceable due to individual efforts by their developers to provide themselves and their fellow citizens with a safe, dry passage from place to place within the city limits.

\section{THE ARTIFACTS}

Next to the architecture and the documentary history of a site, the most reliable and useful resource for identifying and understanding its inhabitants and how they 1 ived are their artifacts. Despite the fact that the city block under investigation had been badly disturbed, making the exact original location of some artifacts within specific areas somewhat open to question, analysis of the artifacts as a whole revealed many details about the inhabitants of the houses and how they 1 ived during various time periods. For convenience in analysis, the artifacts have been divided into use categories. They will be discussed first in these functional groups, and then analyzed with respect to individual residences to discover what the artifacts may reveal about them. Discussion will be related directly to current knowledge of similar artifactual col 1ections from other 18 th and early 19th-century sites in other parts of Texas, particularly in the San Antonio River valley and related areas (Table 1 ).

\section{KITCHEN-DINING}

By far the most numerous artifact types from Laredo pertained to subsistence activities, including the preparation and consumption of food. These items are also the ones containing the most sensitive information on chronology, diet, customs, and social stratification. Each category will be discussed separately, with individual items of interest described within each category (Table 1).

\section{Ceramics}

Ceramics have played a major role in food preparation in Mexico and in the southwestern United States for many centuries. The native peoples made and 


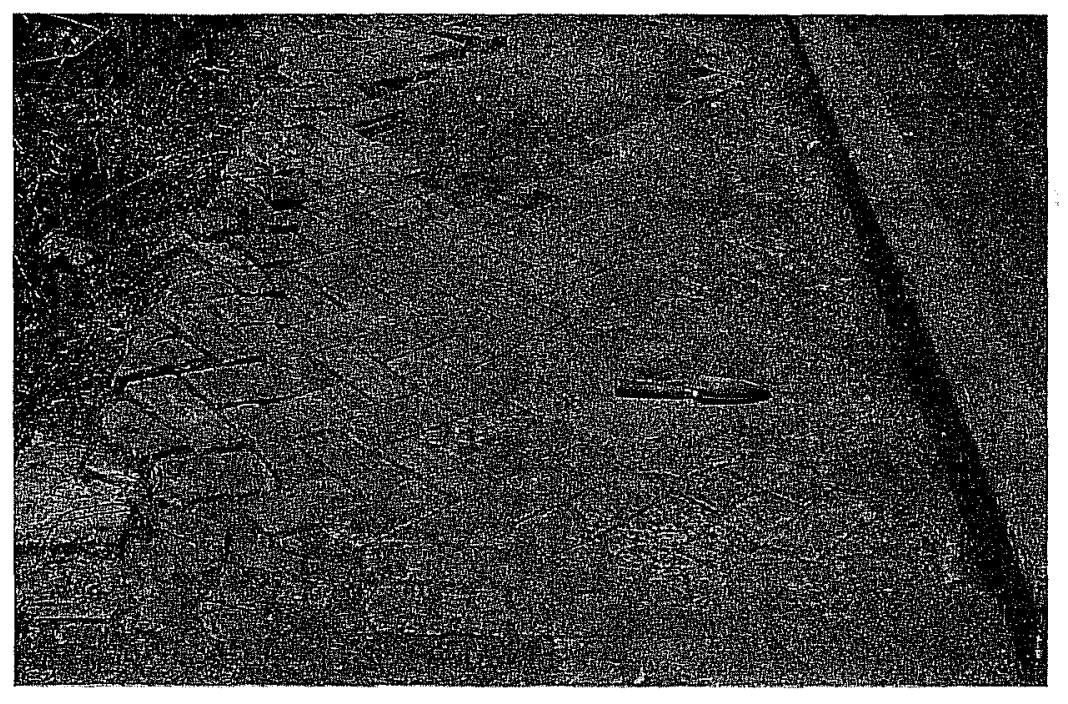

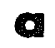

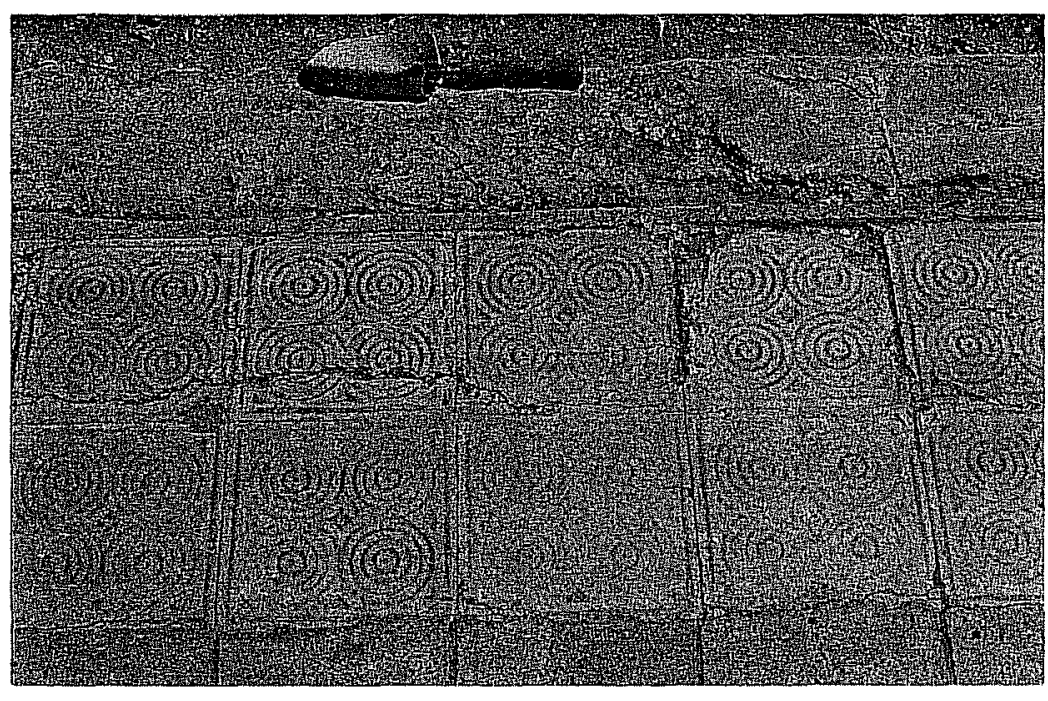

c

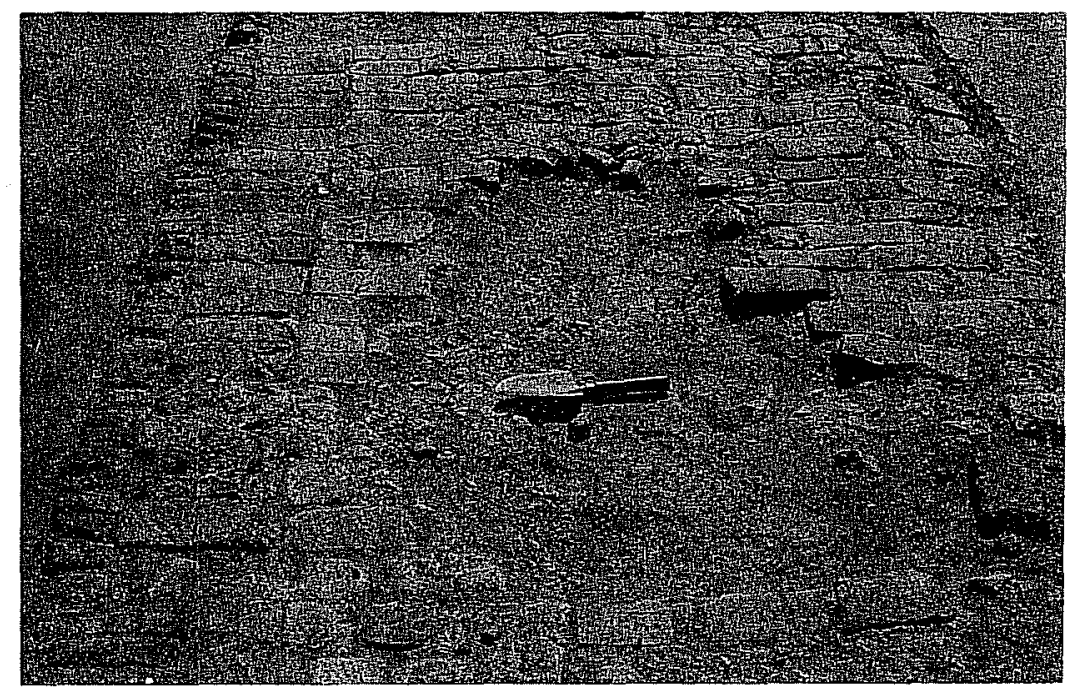

b

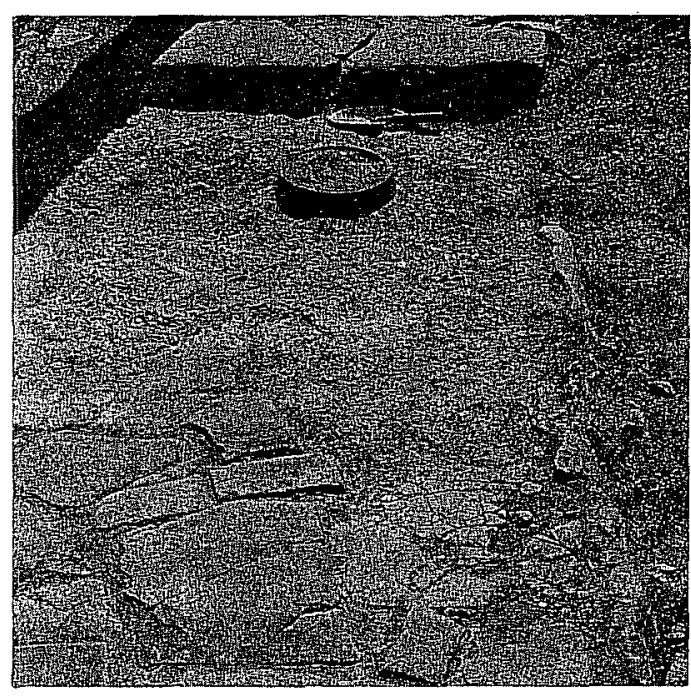

d

Figure 5. Excavations at City Block 12. Shown are differing sidewalk paving along West Zaragoza Street. a, fired red bricks in herringbone pattern; b, fired red bricks in end-to-end pattern; c, ceramic tiles decorated with swirl designs; and d, irregular set flagstones. 
used ceramic vessels before their Spanish conquerors arrived. Gradually the Indian and the Spanish ceramic traditions merged to create a new tradition, combining the native knowledge of clays and their blending and shaping with the European knowledge of glazes and firing techniques. A basic cuisine evolved around the preparation of beans and corn with the addition of meat from locally domesticated animals and those brought from Europe. The merging of these two cultures is still evident in the ceramic pots, jars, and bowls used for the preparation and serving of traditional Mexican dishes today. This merging of Mexican and Spanish culture is particularly well reflected in the microcosm of Laredo examined in this project with, however, a few important exceptions involving stone grinding implements (see below).

Ceramic sherds formed an important part of the artifacts recovered. There were fragments representing the entire span of years during which the town of Laredo was occupied, from the mid-18th century to the present day. Many types of wares, from simple, local1y made utility wares to delicate, imported porcelain cups and saucers, are represented. (To avoid fragmented repetitive references, let it be understood that each of the ceramic types recovered in Laredo has been described in numerous previous reports of excavations in San Antonio and elsewhere across the Southwest and Mexico. Additionally, a 1 ist of references pertaining to ceramics [and other artifacts] is presented in Table 2 to aid the reader unfamiliar with this type of material.)

\section{Unglazed Wares}

Unglazed sherds representing flat-bottomed, deep dishes or bowls made on a potter's wheel were recovered in smal1 quantities. Most sherds are reddish tan with dark cores, indicating low firing temperature. One sherd with traces of a dark red painted design is similar to a type of pottery found on Spanish colonial San Antonio sites (see Greer 1967:19, Type I; Fox, Bass, and Hester 1976:67).

\section{Burnished Wares}

A number of different types of burnished vessels are represented in the collection. Most numerous are sherds of one or more figurines and several smal1 bow 1 s decorated with black and red painted designs on a 1 ight tan body. This type ware was made primarily in Tonala, Jalisco, during the 18 th and 19th centuries. Sherds of a tan-colored ware with a burnished red slip were also present. Some fragments of this type also show traces of blue painted designs. Several dark gray sherds have a mahogany-colored burnished slip on the outside of the vessel. It is interesting to note a total absence of a red, burnished ware present in smal1 amounts on virtually every Spanish colonial site in the San Antonio River valley. This situation could reflect a different source area for Laredo ceramics, or perhaps it may mean that this type ware was not available after the mid-18th century when Laredo was founded. 
TABLE 2. SUGGESTED ARTIFACT REFERENCES

\section{Ceramics: 18th-Century Mexican}

\begin{tabular}{ll}
\multicolumn{2}{c}{ General } \\
Goggin & 1968 \\
Fox & 1977 \\
Seifert & 1977
\end{tabular}

Ceramics: 18th- and 19th-Century English and American

$\begin{array}{ll}\text { McCl inton } & 1951 \\ \text { Noê1 Hume } & 1970 \\ \text { Mi 1 ler } & 1980\end{array}$

Formed Giass

Kendrick 1966

Lorrain 1968

Tableware, Kitchenware, Furnishings

Sears, Roebuck and Co. 1968

Montgomery Ward \& Co. 1969

Clothing and Personal Items

$\begin{array}{ll}\text { Noẻl Hume } & 1970 \text { (buttons) } \\ \text { Luscomb } & 1967 \text { (buttons) } \\ \text { Sears, Roebuck and Co. } & 1968\end{array}$

Activities, Toys, and Amusements

$\begin{array}{lll}\text { Fox } & 1973 \text { (do11s) } \\ \text { Deagan } & 1972 \text { (discs) } \\ \text { Schuetz } & 1969 & \\ \text { Anderson } & 1968 \text { (shoes) } \\ \text { Randa11 } & 1971 \text { (marbles) }\end{array}$

Prehistoric Artifacts

Hester $1980: 98,105$ 
G1azed Ware

Large ollas and bowls of a sandy paste, lead-glazed ware are represented in the collection. This groups also includes a few tripodal molcajetes (grating bowls with striated interiors). The proportion of this type to other types of Mexican-made wares is surprisingly low in comparison to collections from most Spanish colonial sites, here again hinting at a date earlier than 1750 for the highest popularity of these wares.

By far the 1 argest category of Mexican-made utility wares present on this site is the fine-textured, red paste, lead-glazed type ceramic referred to by Southwestern historical archaeologists as Galera ware (Table l). Vessels are thin-walled, primarily mold-made chocolate and bean pots and 011 as. They are glazed primarily on the inside surface, with the glaze at times lapping over the outside rim. Often these containers bear dark brown, cream, and green designs, particularly on the necks of chocolateras and bean pots. This ware does not appear on Spanish colonial sites in Texas until after the mid-18th century, which would exp 1 a in its apparent popularity in Laredo during the 1ate part of the 18th century.

Majolica Wares

Tin-glazed majolica from pottery centers in Puebla, Mexico City, and Guanajuato form a part of the ceramic collections from 18th and early 19thcentury sites in al1 areas of the Southwest. The majolica from Laredo is divided, for convenience, into Early (primarily 18th century) and Late (early 19th century) varieties. Early varieties represented include examples of Puebla Blue-on-White, Huejotzingo, San Elizario polychrome, Aranama polychrome, and Tumacacori wares (Fig. 6,0,p).

Late varieties of majolica are predominantly red-bodied wares made in Guanajuato. They are decorated with rust, green, and ye 110 designs (Fig. $6,7-n, q-t)$. Aside from 19th-century majolicas recovered in 1971 from the south end of Mission San Juan Capistrano (M. K. Schuetz, manuscript in preparation), this is the most varied collection of these wares yet found in Texas (Table I).

\section{Earthenwares}

Cream-colored earthenwares made in England during the 1 ate 18 th century appear in sma11 quantities in many 7 ate colonial deposits. It often is difficult, if not impossible, to differentiate some of these wares from undecorated portions of early 19th-century pearlwares exported all over the world in large quantities by the British in the first part of the 19th century. There is, however, a smal1 group of sherds with a distinct ye 11 ow cast in this collection that may qualify them as the earlier ware.

Undecorated white earthenware, popular up to about 1855, was also present in the collection (Table 1). 
Miscellaneous Wares

The balance of 19th-century ceramics from Laredo are made up of decorated pearlware and late 19th-century ironstone and other white Victorian wares. The pearlwares are decorated in bright, clear colors in a multitude of patterns using a wide variety of techniques. These include transfer printing, sponging, hand painting, and wheel-turned slip decoration.

Sherds of delicate white porcelain plates and cups were recovered from all structures excavated. A few decorated overglaze with decalcomania designs typical of turn-of-the-century wares were recovered. Two sherds are from a dime store Japanese ware popular in the early 20 th century.

Comparatively few sherds were found of the stoneware storage crocks, bottles, and jars so frequent in late 19th-century Anglo sites. This probably reflects differences in cuisine, food preservation, and housekeeping customs between Anglo-American and Mexican households. Surprisingly absent from this col lection are the hard stone manos, metates, molcajetes, and tejolotes used in Mexican households for grinding food and spices for consumption. Nor are there the ceramic comales used to make and reheat tortillas, indicating that either a 11 of these activities were performed by specialists outside the household or that the inhabitants were much more European than Mexican.

In the col1ection, 20th-century wares are represented by brightly colored hand-painted and decal decorated white earthenwares and solid-colored glazes typical of the 1930s. A few sherds of Victorian majolica are also included (Tab Te 1).

\section{Formed Glass Containers}

The formed glass container category consists of blown and machine-made glass bottles and jars, as wel1 as tumblers, mugs, and bowls. A11 time periods are represented, from pontil bottles made prior to 1840 to contemporary soda water bottles. Represented among the pressed $\mathrm{g} l$ ass objects are the hexagonal and octagonal tumblers and 1 arge, heavy goblets and pitchers in popular use throughout Texas in the 1 ate 19th century. References on dating these objects are 1 isted in Table 2.

\section{Iableware}

Fragments of meta 1 , bone, and the wooden handles for forks and knives were found in the excavations, along with the bow 1 from a silver-plated spoon of 1 ate 19 th-century design and a cap for a smal1 tankardlike container. A fragment of a large kitchen knife was recovered from Structure II (Table 1 ).

\section{Miscellaneous Metal}

Numerous fragments of tin cans and other metal containers, as well as pieces of unidentifiable rusted metal were recovered during excavations (Table 1 ). 
Figure 6. Artifacts From the Excavations.

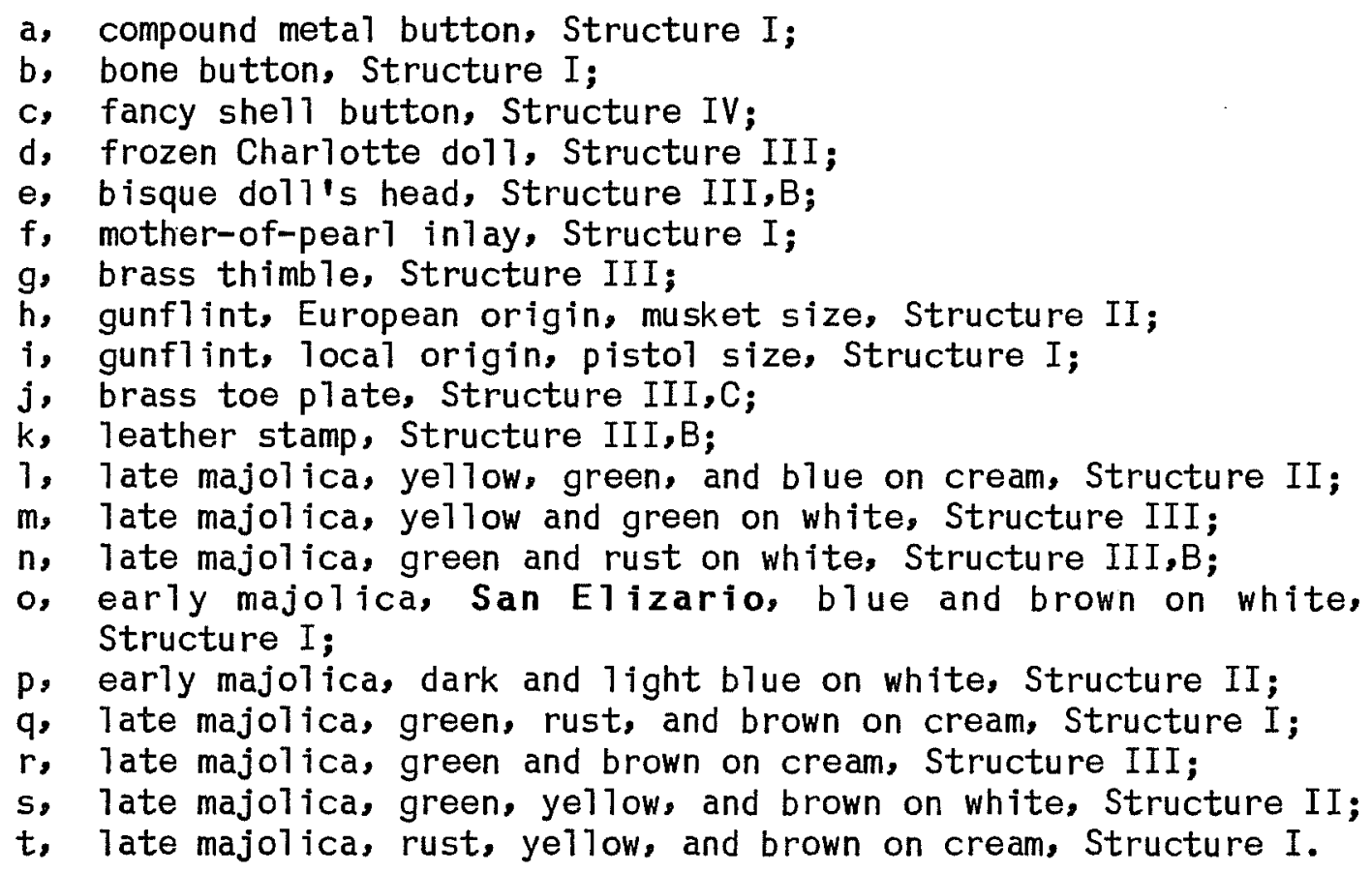




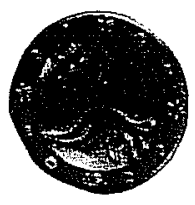

a

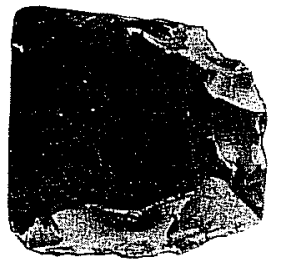

h

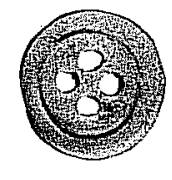

b

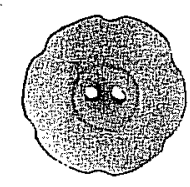

C
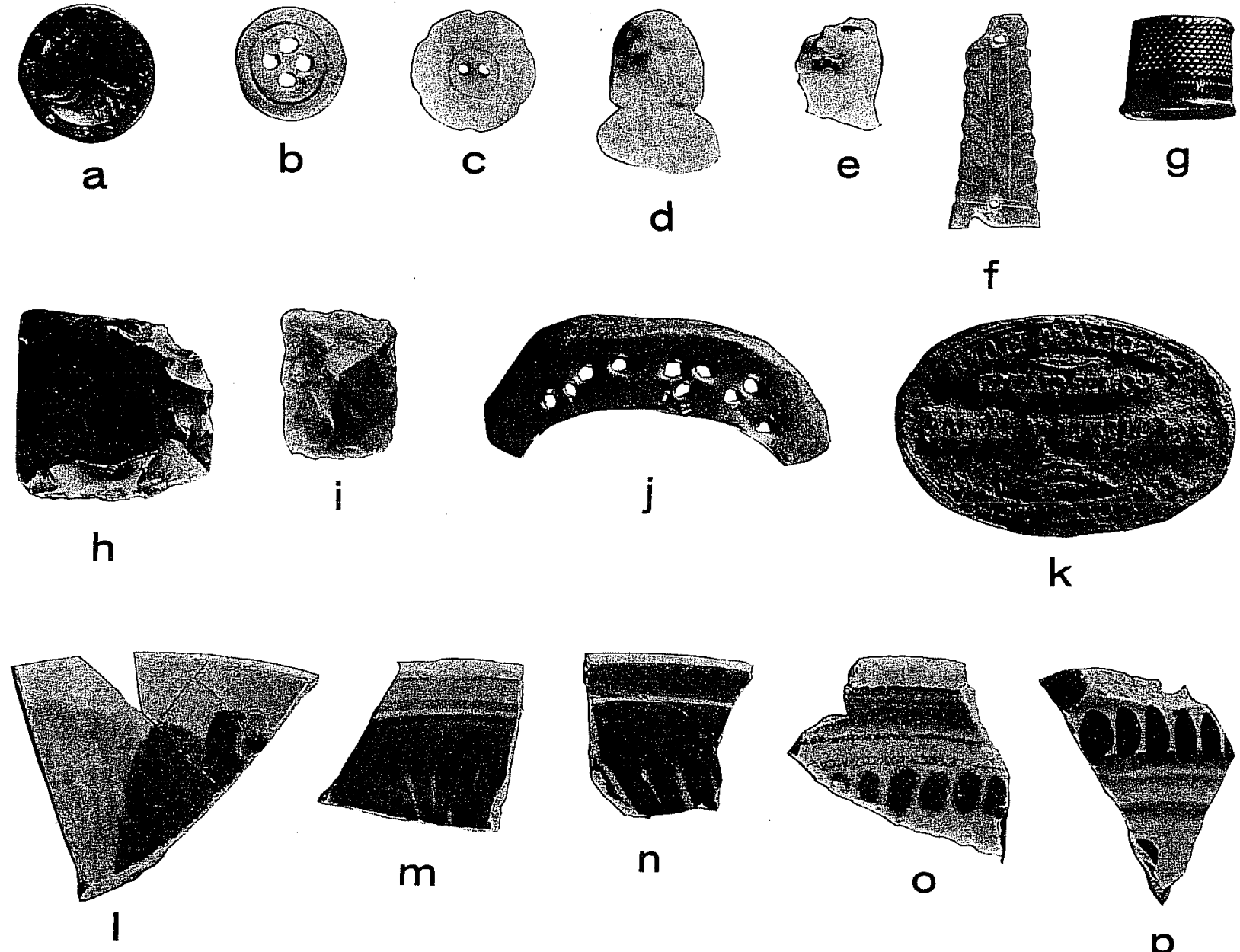

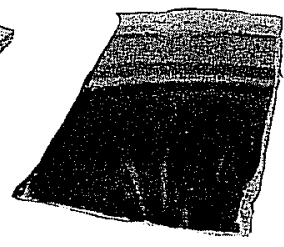

m

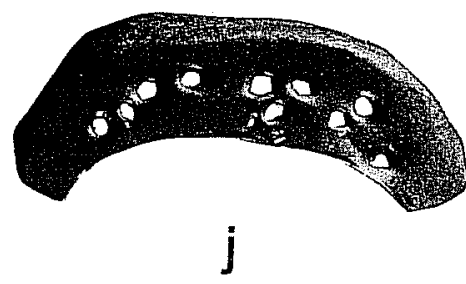

k
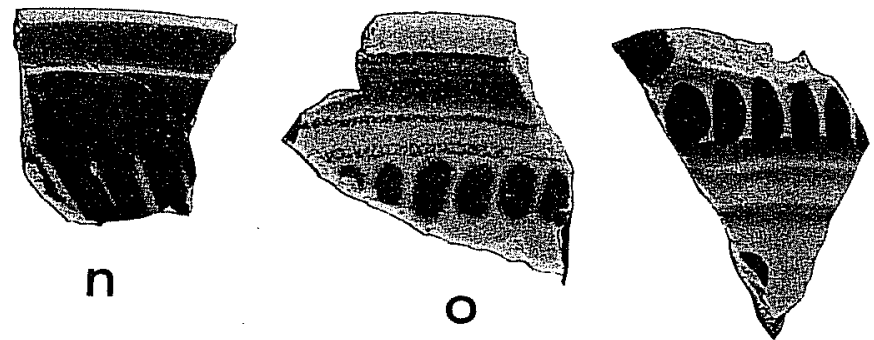

p
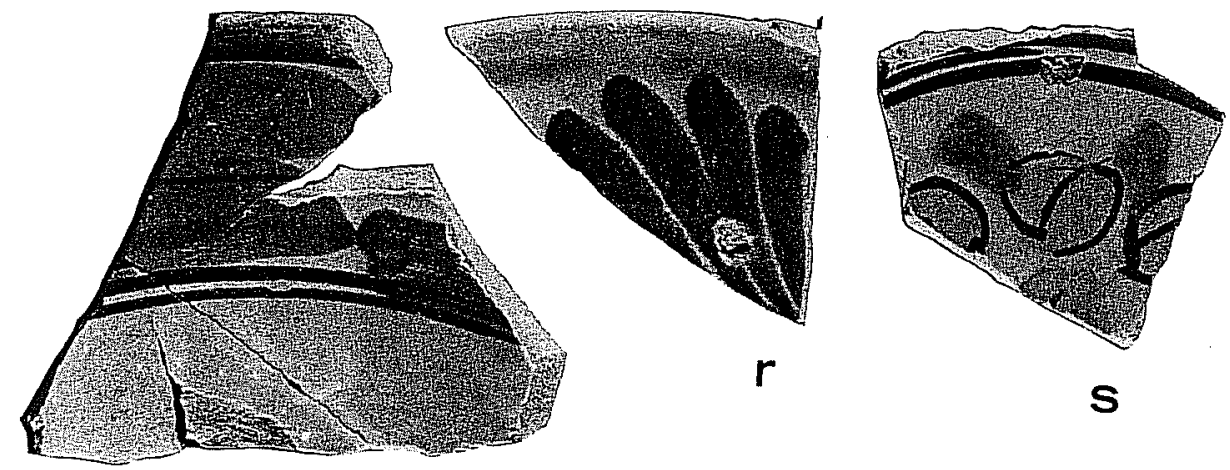

S

$q$
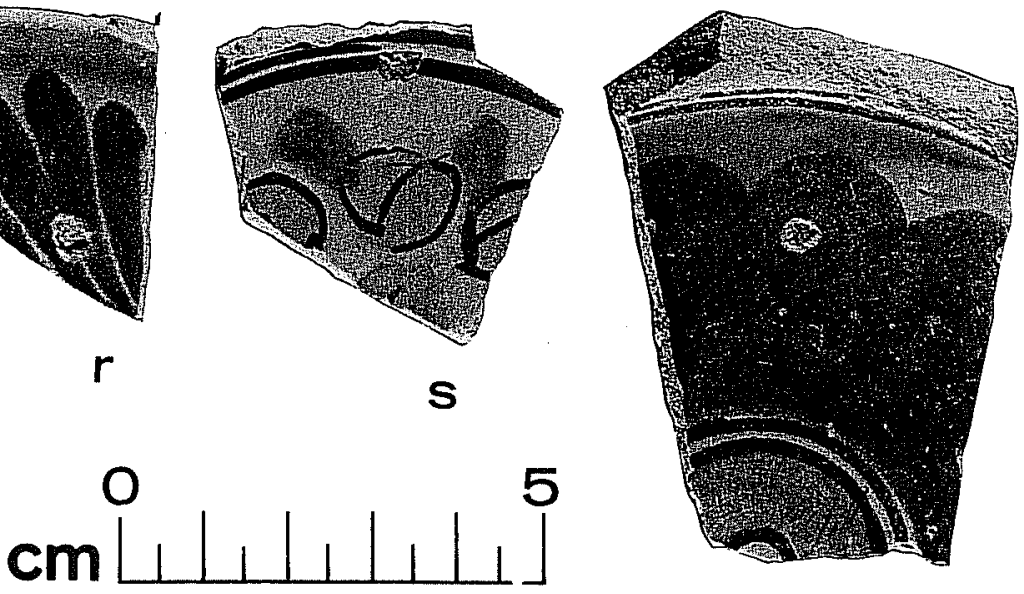
Bone and Shell

The collection of animal bone and river mussel shell from the excavations represents food remains accumulated throughout the occupation of the area. Larger concentrations were found in trash pits and backyard areas. The faunal analysis is included as an appendix to this report.

\section{HOUSEHOLD FURNISHINGS}

\section{Hardware}

Hardware articles recovered are portions of a padlock, a clock gear, a cabinet 1 atch, and metal parts from two 1 ate 19 th-century kerosene 1 amps, a 11 from Structure IV (Table 1).

\section{CLOTHING}

\section{Accouterments}

A number of metal buckles and buck 1 e fragments were recorded, as we 11 as other fasteners such as hooks and safety pins. A11 appear to date from the post-1860 era. Four bone buttons were present, probably dating from the early 1900s (Fig. 6,b). Metal buttons are primarily simple iron buttons from work clothing. One Boy Scout button and two fancy metal buttons with stamped designs were excavated in Structure I (Fig. 6,a). The remainder of the artifacts in this group are more or less even 1 y divided between she 11 and white glass buttons. These are mostly of a smal1 size (ca. $1 \mathrm{~cm}$ in diameter) which were popular on clothing from the 1 ast part of the 19th century (Fig. $6, c)$. A few colored, post-1900 glass buttons and one spherical, contemporary button are also present (Table 1 ).

\section{PERSONAL ITEMS}

Artifacts of a personal nature recovered are a fragment of coral, severa 1 metal jewelry fragments, an assortment of glass beads (primarily contemporary), a brass thimble (Fig. $6, g$ ), an unidentifiable carved bone handle, and mother-of-pearl inlays from a smal1 chest or box (Fig, 6,f). A plastic comb fragment and a single-edged razor blade were a 1 so recorded. Four fragments of clay pipes could be dated on ly to sometime in the 19th century (Table 1).

\section{MISCELLANEOUS ITEMS}

\section{Ioys and Amusements}

Fragments of 1 ate 19 th-century porcelain do $11 \mathrm{~s}^{\prime}$ heads, including arms and feet, and toy tea sets were recorded from a 11 structures (Fig. 6,d,e). The majority came from Structure IV. A variety of marbles were also recovered, with every structure represented. These ranged from turn-of-the-century 
baked clay and glazed crockery marbles to contemporary machine-made swirled glass marbles still in use today (Table 3). A modern bicycle spoke, a plastic toy soldier, and a jack from a contemporary set of ba 11 and jacks were other children's activities represented.

\section{Eishing Equipment}

A lead fishing weight is further indication of subsistence activities involving the nearby river (Table 1 ).

\section{Writing Materials}

Numerous fragments of slates and slate pencils were found in al 1 areas excavated. Metal eraser holders from contemporary wooden pencils and metal pen points were also represented on the site (Table I).

\section{Discoidals}

A total of 48 discs made of ceramic sherds and two of bottle glass was found throughout the site. These discs ranged in size from 0.8 to $6.0 \mathrm{~cm}$ in diameter, and are made of sherds ranging in date from the Spanish colonial to the early 20 th-century period. They were probably counters in some sort of popular local game, or perhaps used for accounting purposes. Similar discs made of ceramic sherds are found on Indian and Spanish sites throughout Mexico and the Southwest. Four flat, discoidal river pebbles from the site may have had a simitar use.

Another discoidal object which might be included in this group is a thin lead disc with a vague impression of what may be a religious design (numerous fine rays radiating from the center toward the outer edges). Similar lead discs found in Spanish colonial sites in Texas can generally be identified as seals for bales of blankets or cloth brought in by traders (Table 1 ).

\section{Shoe Leather and Related Artifacts}

A 1 arge number of 1 eather fragments, in addition to shoe soles and heels, were recorded in Feature 8 of structure IV (Table 1). In 1935, this structure was the residence of a shoe salesman. It appears, however, that a certain amount of 7 eather goods repairing was also taking $p 1$ ace in this structure at some point in time. Two brass toe plates used on shoes in the period following the Civil War were also found there (Fig. $6, j)$. In that most of the leather scraps show signs of sewing, this would date them to sometime after 1860 when shoe soles first began to be sewed to the uppers (Anderson 1968). A carved leather stamp found in the same area reads (in reverse) "PRISCILIANO FLOYD/COMERCIANTE/POR MAYOR Y MENOR/LAREDO, TEXAS" (Fig. 6,k). Perhaps a Mr. Floyd rented this structure sometime around the turn of the century, or the stamp was made here for his business located at another address. No documentary information was found on this person. 
TABLE 3. ARTIFACTS, MARBLES

\begin{tabular}{|c|c|c|c|c|}
\hline Description & Manufacture* & Diameter & Structure & Quantity \\
\hline stone & Germany, mid-19th century & $1.9 \mathrm{~cm}$ & III,B & 1 \\
\hline crockery & late 19th-century & $1.7 \mathrm{~cm}$ & II & 1 \\
\hline crockery & late 19th-century & $1.9 \mathrm{~cm}$ & II & 1 \\
\hline crockery & late 19th-century & $2.0 \mathrm{~cm}$ & II & 1 \\
\hline "china" or porcelain & last third of 19th-century & $1.9 \mathrm{~cm}$ & II & 2 \\
\hline clay & U.S., 1ate 19th-early 20th centuries & $1.3 \mathrm{~cm}$ & I & 1 \\
\hline clay & U.S., late 19th-early 20 th centuries & $2.5 \mathrm{~cm}$ & III, IV & 3 \\
\hline clay & U.S., 1ate 19th-early 20 th centuries & $2.6 \mathrm{~cm}$ & III & 1 \\
\hline clay & U.S., late 19th-early 20th centuries & $2.7 \mathrm{~cm}$ & III, IV & 2 \\
\hline clay & U.S., late 19th-early 20th centuries & $2.8 \mathrm{~cm}$ & I & 1 \\
\hline glass & U.S., machine-made, ca. 1905 to present & $1.4 \mathrm{~cm}$ & I & 1 \\
\hline glass & U.S., machine-made, ca. 1905 to present & $1.5 \mathrm{~cm}$ & I. III & 2 \\
\hline glass & U.S., machine-made, ca. 1905 to present & $1.6 \mathrm{~cm}$ & I; III,B; IV & 3 \\
\hline glass & U.S., machine-made, ca. 1905 to present & $1.7 \mathrm{~cm}$ & III & 1 \\
\hline glass & U.S., machine-made, ca. 1905 to present & $2.0 \mathrm{~cm}$ & III,B & 1 \\
\hline
\end{tabular}

*Sources: Block 1979:150-158; Roberson 1974:51-52. 
Stable and Workshop Artifacts

A broken horseshoe and the brass bindings from a late 19th-century carpenter's rule were recovered from the excavations (Table 1).

\section{MUNITIONS}

An interesting assortment of ammunition and related items were excavated from this site. These artifacts, identified by Robert Patton of the CAR staff, represent a wide range of weapons, including a 12 gauge shotgun, a Spencer repeating carbine of 1861-1865 vintage, a later mode1 Spencer carbine, a Henry rifle and/or Winchester rifle of Civil War or later 19th-century times, and a number of other 1 ate 19th-century and early 20th-century arms. A1so included is one .50 caliber machine gun bullet of World War II date (Table 4).

\section{CONSTRUCTION MATERIALS}

Large amounts of windowpane $\mathrm{g} 1$ ass and nails were recovered from the site. The glass varies from $2 / 32$ to $3 / 32$ inches in thickness.

A few fragments of plate glass as thick as 5/32 inch were found in Feature 9. There is no observable pattern to the distribution, and the measurements fall within the range of modern window glass.

Of the nails recovered, $20 \%$ are wire nails, which were not in common use in Texas until approximately 1900 . The balance of the nail collection consists of common cut nails of various sizes from $2 d$ ( 1 inch) to $16 d$ ( 3.5 inch), with a few as large as $50 \mathrm{~d}(5.5 \mathrm{inch})$. The on $7 y$ noticeable difference in distribution is in the 7 arger percentage of wire nails from Structure II, which may reflect post-1900 remodel 1 ing such as the construction of the bathroom at the rear of the house. A few galvanized roofing nails were recovered from Structures I, II, and IV, probably from 20th-century roofing repairs or replacement. While the sample is not adequate to make a positive statement about the absence of hand wrought nails representative of 18 thcentury construction on the site, this lack in the collection could be significant as an indicator of the sorts of construction first used in the area.

A heavy, hand-forged gate hinge of a type popular on farms and ranches since the mid-19th century and a fragment of a cast iron turn-of-the-century door latch were the only two recovered artifacts considered as building hardware. Fragments of porcelain electric fixtures and carbon battery cores were found on the site. Samples of various types of brick and tile were also collected from each structure (Table 1). 
TABLE 4. ARTIFACTS, ARMS

\begin{tabular}{|c|c|c|c|}
\hline Item & Lot & Ouantity & Description \\
\hline 1 & 3 & 1 & $\begin{array}{l}12 \text { gauge shotgun she } 11 \text {, DuPont Cartridge Co., } \\
\text { Wilmington, Delaware }\end{array}$ \\
\hline 2 & 3 & 2 & $\begin{array}{l}.56 \text { caliber rimfire Spencer cartridge, manu- } \\
\text { factured in } 1861-1920 \text { for Spencer repeating } \\
\text { carbine and rifle of } 1861-1865\end{array}$ \\
\hline 3 & 3 & 1 & .56 caliber bullet, probably for above \\
\hline 4 & 3 & 1 & $\begin{array}{l}.50 \text { cal iber machine gun bul1et, World War II } \\
\text { vintage }\end{array}$ \\
\hline 5 & & & $\begin{array}{l}.56 \text { caliber center fire, probably for a } 1 \text { ater } \\
\text { model Spencer }\end{array}$ \\
\hline 6 & & & top to a primer container \\
\hline 7 & 2,3 & 2 & $\begin{array}{l}.44 \text { cal iber rimfire Henry cartridges, used in } \\
\text { the Henry rifle (1860-1865) and the mode1 } 1866 \\
\text { Winchester rifle (1866-1873; 1875-1898) }\end{array}$ \\
\hline 8 & & & .22 caliber rimfire cartridges, miscellaneous \\
\hline 9 & 3 & 1 & .35 caliber bullet, copper jacket \\
\hline 10 & 1 & 1 & .25 caliber bullet, copper jacket \\
\hline 11 & 1 & 1 & .32 caliber bullet, lead \\
\hline 12 & 1,4 & 2 & $\begin{array}{l}.38 \text { caliber Winchester center fire cartridges, } \\
\text { used in Model } 1873 \text { and Model } 1892 \text { Winchester } \\
\text { rif } 1 \text { es, colt single action pistols and a } \\
\text { multitude of other weapons manufactured from } \\
1880 \text { to present }\end{array}$ \\
\hline 13 & 3 & 2 & percussion caps, 4-wing or top hat variety \\
\hline 14 & 1,2 & 2 & gunflints (Fig. $6, h, i$ ) \\
\hline
\end{tabular}




\section{CHERT}

As might be expected from an elevated terrace on the Rio Grande, traces of a prehistoric occupation were present among the artifacts of a 1 ater civilization. A total of 80 chert flakes, chunks, and fragments was recovered, of which four appear to be fragments of bifacial tools, and one is an alternately beveled, triangular projectile point with a basal notch. This artifact most closely resembles a typical south Texas Tortugas point prior to 1300 B.C., although the basal notch also would seem to relate it to the Carrizo point type more common farther north in Dimmit, Zavala, LaSal1e, and Frio Counties. This would tentatively date a prehistoric occupation of the area to the Middle Archaic period (Table 1).

\section{OBSERVATIONS AND COMPARISONS OF THE LAREDO ARTIFACTS}

It is interesting to see 18th-century ceramics recovered from a section of a mid-18th-century town officially occupied on $7 y$ after the mid-19th century according to local archival records. The even distribution of this variety of ceramics over the entire area excavated suggests that something connected with the earlier history of the town was taking $p 1$ ace in this area before 1850. However, the nature of this activity was not indicated by the artifact inventory.

In comparing the ceramic totals from the most completely sampled structures, one is struck by the similarity of the assortments. There is, however, a notable difference in the percentages of Mexican-made vs. Anglo ceramics. Structures I, II, and III contained $42 \%$ Mexican ceramics and 58\% Anglo, whereas in Structure IV the percentages were reversed, with 53\% Mexican and 47\% Anglo. Several interpretations could be made of these statistics. It could reflect a more intense period of occupation during the 1 ate 18th and early 19th centuries in Lot 3, a different cultural or social background among the tenants 1 iving on this lot, or it could merely represent sampling differences during excavation. It is unfortunate that the site was too badly disturbed to make possible a more confident conclusion on this difference.

Analysis of other categories of artifacts does not suggest any other differences between the material culture associated with the structures, other than an apparent absence of 20 th-century ceramic types from Structures II and III.

In comparison with 19th-century residential sites excavated in the rest of the state, the proportions of Mexican-made ceramics from Laredo are very high, as might be expected from a population of Mexican derivation in close proximity to the source of supply. What appears to be a shift to whitewares in the early 19th century (with the probable exception of Galera ware which continued in use) is similar to what happened in Spanish-speaking households in San Antonio, Gol jad, and Victoria (see Schuetz 1969; Fox 1977; Fox and Livingston 1979). The outstanding difference between Laredo and the rest of the state appears to be the continuing prevalence of Galera ware sherds in 1 arge numbers on the Laredo site in comparison to other sites excavated in Texas. 


\section{SUMMARY AND CONCLUSIONS}

B1ock 12, Western Division, demonstrates a history of human occupation and development dating back to approximately 1800 B.C. It was at this time that the area was inhabited by hunters and gatherers of the Middle Archaic period who probably camped on the bluff overlooking the shores of the Rio Grande from time to time, either when traveling along the river in search of subsistence and sheiter, or perhaps in crossing from one side to another.

The first indication of European occupation in Laredo is in the form of 18 thcentury colonial Mexican ceramics. These had probably been brought and left there by early peoples 7 iving in the temporary dwe 11 ings referred to as jacales by Tienda de Cuervo in 1757 (Bolton 1902:191). Unfortunately, such ceramics were not detected during this project by the crew due to the narrowness of the trenches. In that each family colonizing Laredo was granted up to 10,000 acres along the Rio Grande, the area that was to become Block 12, Western Division of Laredo was at least owned by someone during the mid-18th century. This would suggest that one could expect some type of human activity in this area, especially since it was located only a block or so from the center of town, which would have been inhabited by the highest ranking families of Laredo, as was the case with virtually al1 preindustrial societies. The mixture of both Mexican and Anglo ceramics in Block 12 reflects not only the nearby sources of these materials, but also the Mexican, Spanish, and American sovereignty over the region. The various types of artifacts also attest to the occupation at one time or another by the armies and civilians of the various countries that were involved in the 1 arge turnover of the Laredo population through time. It may be suggested, however, that the apparent absence of stone manos, metates, malcojetes, tejolotes, and ceramic comales either used for grinding corn, chocolate, coffee, and spices and for making tortillas suggests that the early population was more of Spanish than Mexican-Indian extraction.

The fact that the population of Laredo jumped from on $7 y 85$ peop 7 e in 1755 to over 700 by 1789 would suggest expansion away from the central plaza and thus a wider dispersion of dwellings and artifacts. But not until 1855 do we have written records for who occupied Block 12 and, through excavation, what type structures they 1 ived in was revealed.

Following the arrival of the Texas-Mexico and the International Great Northern Railroad in 1881, the population of Laredo began to swell rapid1y, reaching 11,000 citizens by 1890 . It was around this time that the adobe and stone house on the corner of West Grant Street and Santa Ursula Avenue appears in Sanborn's 1885 map of Laredo (Sanborn Map and Publishing Company, Ltd. 1885; see Fig. 2,a). Although the area to the west of Block 12 was fairly well developed at this date, the area to the east of the stone and adobe house is not even included in Sanborn's 1885 or 1889 maps (ibid.; see Fig. 2,a,b), perhaps suggesting that these lots were unoccupied or that the structures erected there were not considered insurable by this company.

Further indication as to why the area to the east of Structure I is not included on Sanborn's early maps is manifested by the continued presence of at least one thatched roof building on the corner of West Zaragoza and San 
Bernardo Streets in addition to the wooden structure located behind the stone and adobe house on Lot 1, 1 ater referred to as one of the three "Mex. Shanties" on Sanborn's 1894 map of Laredo (Sanborn Map and Publishing Company, Ltd. 1894; see Fig. 2,c). This, in addition to Cuervo de Tienda's mid-18th century remark concerning jacales, provides us with sufficient reason to suggest that our remarks regarding the habitation of $B 1$ ock 12 by people living in temporary structures during the 18th century is not too far from wrong. That this type of temporary dwelling continued to be used until 1885 (and later) as suggested by the above would also further qualify these structures as not being very insurable by Sanborn's and, therefore, not worth recording on their 1885 map ( $F$ ig. 2 , a).

By 1890, however, the situation seems to have changed in Laredo and in Block 12, according to the "Perspective Map of the City of Laredo, Texas," drawn ca. 1890 (Reps 1973:641). At this time Laredo is depicted as a thriving, fully developed industrial center with electricity and even six miles of electric street railway, built mostly with the idea of attracting "men of push and energy" as we11 as new industry to take advantage of local

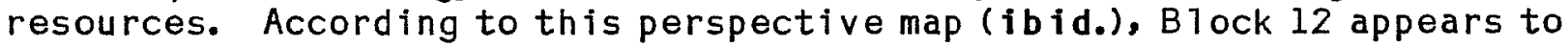
have undergone a metamorphosis by this time, giving the appearance of a fully occupied section of Laredo located approximately halfway between the plaza principa 1 and the main industrial complex on the far side of Chacon Creek. On Sanborn's map of 1894 (Sanborn Map and Pub1 ishing Company, Ltd. 1894; Fig. $2, c)$, six out of 10 lots on Block 12 are shown with stone or brick buildings, with Structure I as the only building built partially of adobe still existing at that time. There still existed, even at this date, several wooden structures labeled "Mex. Shanties" and many thatched roof buildings, suggesting that $B$ lock 12 represented a mixture of both the new and the old in 1894--a lower class neighborhood on the road to middle class status.

The demolition of Structure I (Lot 1) and Structure IV (Lot 3), the construction of brick houses, the shift from building habitations flush with the street or sidewa $1 k$, and the formation of front and rear porches and front yards demonstrate a move away from the Mexican manner of building to one favored by Anglos as wel1 as second and third generation Mexican-Americans. In the same way that the above features suggest class and generational changes, the leather shop occupying Structure IV, Lot 3 is a precursor of the spread of the downtown Laredo business district to the nearby suburbs, a trend that has continued up to the present day. In addition, just as the area was possibly chosen as a crossing point on the Rio Grande by Middle Archaic peoples in search of something different (if one is to accept 1ocal rumors) it also serves as a crossing for modern Mexicans from Nuevo Laredo into the United States. The location of the new International Bridge and its Tol 1 Plaza in this same area is merely the most recent event in a long continuation of river crossings that have endured for approximately 3500 years in the area occupied by B 1 ock 12 in the Gateway community of Laredo, Texas. 
RECOMMENDATIONS

The Tol1 Plaza area should be left as undisturbed as possible. If it is to be used for future construction purposes, it is suggested that. a minimum number of subsurface excavations as deemed absolutely essential to complete the project be performed.

If the vicinity is once again excavated archaeological1y, is is suggested that the early structures resembling jacales be investigated, along with the "Mex. Shanties" behind Structure I, Lot 1. This should be done to determine their date of original occupation and the ethnic and class background of their inhabitants. If, for example, the shanties were in fact occupied by Mexicans, they should contain more Mexican-type ceramics than Structures $I$, II, III, and IV, in addition to the stone manos, metates, molcajetes, tejolotes, and ceramic comales that were not recorded in association with these structures. Also, further investigation of the prehistoric occupation of the area should be initiated.

In addition to the above suggestions, it seems logical to think in terms of test excavations in Nuevo Laredo, Mexico. Such activities would make possible an archaeological comparison between these two 1 inked settlements in light of their relationship to each other through time.

\section{REFERENCES CITED}

Almaraz, F. D., Jr.

1979 Crossroad of Empire. The Church and State on the Rio Grande Frontier of Coahuila and Texas, 1700-1821. Center for Archaeological Research. The University of Texas at San Antonio, Archaeology and History of the San Juan Bautista Mission Area, Coahuila and Texas, Report 1.

Anderson, A.

1968 The Archaeology of Mass-Produced Footware. Historical Archaeology $2: 56-65$.

Arguindegui and McDonel 1

1900 General Directory of the City of Laredo. P. E. Arguindegui Printing House, Laredo.

Bass, F. A., Jr., and T. R. Hester

1975 Archaeological Survey of Areas S1ated for Modification, Laredo International Bridge II, City of Laredo, Texas. Center for Archaeological Research, The University of Texas at San Antonio, Archaeological Survey Report 14. 
Block, S. A.

1979 Marbles, Playing for Fun and for Keeps. The Encyclopedia of Collectibles. Time-Life Books, Alexandria, Virginia.

Bolton, H. E., translator

1902 Tienda de Cuervo's Ynspeccion of Laredo, 1757. Southwestern Historical Quarterly 6:187-203.

Campbe1 1, T. N.

1979 Ethnohistoric Notes on Indian Groups Associated with Three Spanish Missions at Guerrero, Coahuila. Center for Archaeological Research. The University of Texas at San Antonio, Archaeology and History of the San Juan Bautista Mission Area, Coahuila and Texas, Report 3.

Deagan, K. A.

1972 Fig Springs: The Mid Seventeenth Century in North Central Florida. Historical Archaeology 6:23-46.

Eaton, J. D.

1981 Guerrero, Coahuila, Mexico. A Guide to the Town and Missions. Guia de 1 a Ciudad y de 1 as Misiones. Center for Archaeo10 ical Research. The University of Texas at San Antonio, Archaeology and History of the San Juan Bautista Mission Area, Coahuila and Texas, Report 4.

Epstein, J. F., T. R. Hester, and C. Graves, editors

1980 Papers on the Prehistory of Northeastern Mexico and Adjacent Texas. Center for Archaeological Research. The University of Texas at San Antonio, Special Report 9.

Fox, A. A.

1977 Ceramic Comparisons. In The Archaeology and Ethnohistory of the Gateway Area; Middle Rio Grande of Texas. Report to the National Endowment for the Humanities. On file, Center for Archaeological Research, ihe University of Texas at San Antonio.

1980 Laredo City Tol1 Plaza. Manuscript on file, Center for Archaeological Research. The University of Texas at San Antonio. 
Fox, A. A., F. A. Bass, Jr., and T. R. Hester

1976 The Archaeology and History of Alamo Plaza. Center for Archaeological Research. The University of Texas at San Antonio, Archaeological Survey Report 16.

Fox, A. A. and K. Livingston

1979 Historical, Architectural, and Archaeological Investigations at the Steiner-Schob Complex, Victoria County, Texas. Center for Archaeological Research. The University of Texas at San Antonio, Archaeological Survey Report 52.

Fox, C.

1973 The Do11. Harry N. Abrams, Inc., New York.

Fox, D. E.

1979 Archaeological Testing at Fort McIntosh, Laredo Junior Col lege Campus, Laredo, Texas. Center for Archaeological Research, The University of Texas at San Antonio, Archaeological Survey Report 68.

Fox, D. E. and H. G. Uecker

1977 An Archaeological Study of the McPherson Road Extension Project, Laredo, Texas. Center for Archaeological Research, The University of Texas at San Antonio, Archaeological Survey Report 45.

Garcia, R. 0 .

1970 Dolores, Revilla, and Laredo: Three Sister Settlements. Texian Press, Waco.

Garza, P.

1975 Plan of Block 12 and 27 of Laredo, Texas. On file, Laredo City Engineers Office.

Goggin, J. M.

1968 Spanish Majolica in the New World: Types of the Sixteenth to Eighteenth Centuries. Yale University Publications in Anthropology 72.

Greer, J. W.

1967 A Description of the Stratigraphy, Features and Artifacts from an Archeological Excavation at the Alamo. State Building Commission, Archeological Program, Report 3. 
Gulick, C. A., editor

1927 The Papers of Mirabeau Buonaparte Lamar. Vol. 4. A. C. Baldwin \& Sons, Austin.

Ha11, G. D.

1973 Archeological Survey of Zacate Creek, Webb County, Texas. Report on file at the Texas Archeological Survey, The University of Texas at Austin.

Hester, T. R.

1980 Digging Into South Texas Prehistory. Corona Publishing Company, San Antonio.

Hi11, T. C., Jr.

1971 Letter to Dee Ann Story dealing with archaeological sites on Chacon Creek, Webb County, Texas. On file, Texas Archeological Research Laboratory, Austin.

Hinojosa, G. M.

1979 Settlers and Sojourners in the Chaparral: A Demographic Study of a Borderlands Town in Transition, Laredo, 1775-1870. Unpub 1 ished Ph.D. dissertation presented to the Faculty of the Graduate School of The University of Texas at Austin.

Ivey, J. E., T. M. Medlin, and J. D. Eaton

1977 An Initial Archaeological Assessment of Areas Proposed for Modification at Fort McIntosh, Webb County, Texas. Center for Archaeological Research, The University of Texas at San Antonio, Archaeological Survey Report 32.

Jackson, C. H.

1935 Laredo, Texas, City Directory. C. H. Jackson Directory Co., San Antonio.

Kel1y, T. C.

1979 An Archaeological Reconnaissance of the Palafox Mining Area, Webb County, Southern Texas. Center for Archaeological Research, The University of Texas at San Antonio, Archaeological Survey Report 71.

Kendrick, G.

1966 The Antique Bott1e Col1ector. Edwards Brothers, Ann Arbor, Michigan. 
Laredo City Directory

1855-1868 Libro Titulado Venta de Solares que 1a H. Corporacion ha Venido Desde el año de 1855, Hasta el 1868, y se Siguen $p^{a}$ Adelante con Arreglo al Mapa de esta Ciudad. City of Laredo, City Secretary's Office, Laredo.

Lorrain, D.

1968 An Archaeologist's Guide to Nineteenth Century American Glass. Historical Archaeology 2:35-44.

Luscomb, S. C.

1967 The Collector's Encyclopedia of Buttons. Crown Publishers, New York.

Milier, G.

1980 Classification and Economic Scaling of 19th Century Ceramics. Historical Archaeology $14: 1-40$.

Montgomery Ward \& Co.

1969 Catalogue No. 57, Spring \& Summer, 1895. Dover Publications, Inc., New York.

MCClinton, K. M.

1951 Antique Collecting for Everyone. Bonanza Books, New York.

Nance, J. P.

1963 After San Jacinto: The Texas-Mexican Frontier, 1842. University of Texas Press, Austin.

Noē1 Hume, I.

1970 A Guide to Artifacts of Colonial America. Alfred A. Knopf, New York.

Palacios, J. F. and J. de Ossorio

1767 Acta de la Visita de Laredo. Texas State Archives, Austin.

Payne, F. B.

1913 General Directory of the City of Laredo. F. B. Payne \& Company, Laredo, Texas. 
Peavy, W. G.

1971 Letter dealing with archaeological sites on Chacon Creek, Webb County, Texas. On file, Texas Archeological Research Laboratory, Austin.

Randa11, M. E.

1971 Early Marbles. Historical Archaeology 5:102-105.

Reps, J. W.

1973 Cities of the American West, A History of Frontier Urban

Planning. Princeton University Press, Princeton.

Roberson, W. R.

1974 The Carrington-Covert House: An Archeological Investigation of a 19 th Century Residence in Austin. Texas. Texas Historical Commission, Report 25.

Sanborn Map and Publishing Company, Ltd.

1885. Maps of Laredo, Texas. New York

1889,

1894

Schuetz, M. K.

1969 The History and Archeology of Mission San Juan Capistrano, San Antonio, Texas. Vol. II. State Building Commission, Archeological Program, Report 11.

Sears, Roebuck and Co.

19681897 Sears Roebuck Catalogue. Chelsea House, New York.

Seifert, D. J.

1977 Archaeological Majolicas of the Rural Teotihuacan Valley, Mexico. Ph.D. dissertation, University of Iowa, Iowa City.

Shiner, J. L.

1969 Component Analyses for Archaic Sites. Bul1etin of the Texas Archeological Society 40:215-229.

Texas Almanac

1950 Dallas Morning News, Dallas. 
Thompson, J. D.

1974a Historical Study of Laredo; A Study Prepared for Mayor J. C. Martin, the City Council, and the City of Laredo, Jan. Il, 1974. Laredo City Library.

1974b Sabers on the Rio Grande. Presidial Press, Austin.

Webb County, Texas

Webb County Deed Records (WCDR)

Volumes 4, 8, 9, 10, 14, 27, 43, 59,60,61, 169, 212, 255, 429, and 439. Laredo, Texas.

Probate Records

File Nos. 2628, 190016. Laredo, Texas.

Wilcox, S. S.

1941 The Laredo City Elections and the Riot of 1886. Southwestern Historical Ouarterly $45: 1-23$.

1946 The Spanish Archives of Laredo. Southwestern Historical Quarterly 49:341-360.

Wilkinson, J. B.

1975 Laredo and the Rio Grande Frontier. Jenkins Publishing Co., Austin. 


\author{
APPENDIX \\ NOTES ON THE FAUNAL COLLECTION FROM \\ THE LAREDO CITY TOLL PLAZA EXCAVATIONS
}

Rebekah Halpern

The animal bones recovered from the Laredo City Tol 1 Plaza excavations have been identified and analyzed using the comparative collections of The University of Texas at Austin Paleontological Laboratory. The col1ection was found to include the following species:

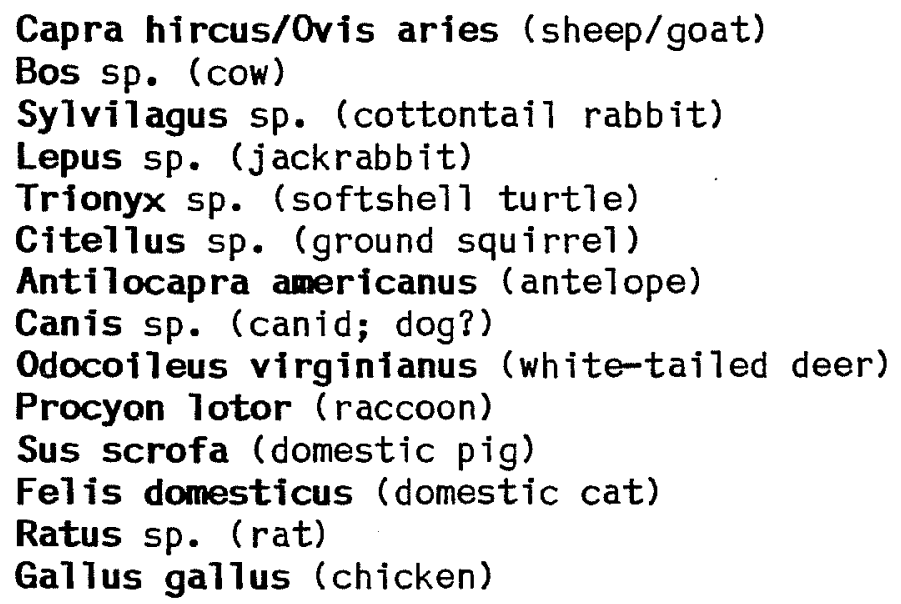

Also present are various species of unidentifiable materials representing fow 1 , frog, duck, hawk, and elements of fish which may be gar. Much of the bone is in very poor condition, and a complete picture has been difficult to obtain.

Animals that appear to have been butchered are mainly sheep and/or goats and cattle. They were machine butchered into cuts of meat such as (in order of frequency) scapular portions, ribs, vertebrae, pelvic and long bone-essential1y the same cuts of meat as today. It appears that the deer or antelope, birds, etc., were quartered rather than saw-cut.

Apparently none of the butchered bone was sawn by hand (determined by the pattern of the cut). Hand-sawing would probably have been used during an early (i.e., Spanish) occupation, while machine-cutting would have been used by both Mexican and Anglos in a later period, primarily at butcher shops.

It is interesting to note that some of the sheep and/or goats were butchered before the age of 36 months, the majority being 33 months, which for a sheep and/or goat is subadult age. This is similar to current practice. General1y the younger males are weeded out and the females kept for breeding. However, not al 1 of the material is subadu1t; in fact, the great majority is adu $7 t$. The cattle are all adult, with one juvenile (28 months).

Structure III yielded the majority of deer, and most of the pig bone. Only one other possible pig bone was found elsewhere on the site. The bone from 
this structure was in the worst condition. Structure II contained the most bone of cattie.

Fow 1 and/or chicken seems to have been a wel1-used source of protein. Unfortunately the ducks were not identifiable as to species. However, they may be migratory as Laredo is on the path for some species on their way to Mexico.

In conclusion, the animal bone recovered from the site appears to reflect primarily a 19th- and 20th-century occupation. The diet included main 1 y domestic beef and sheep and/or goat meat, along with some pork and chicken, and supplemented by deer and other wild game. Cuts utilized were similar to those popular today in Texas.

The faunal collection from the Laredo City Tol1 Plaza excavations is curated at the Center for Archaeological Research. The University of Texas at San Antonio. It is available, along with the author's detailed notes, for future researchers. 